\title{
Tasarruf Finansman Sözleşmesi *
}

\author{
Nurtaç ENDES SELVI
}

Araştırma Görevlisi, Selçuk Üniversitesi, Hukuk Fakültesi, Hukuk Bölümü., nurend@ gmail.com, (Sorumlu Yazar / Corresponding Author)

\begin{tabular}{|c|c|}
\hline Makale Bilgileri & ÖZ \\
\hline $\begin{array}{l}\text { Makale Geçmişi } \\
\text { Geliş: 15.05.2021 } \\
\text { Kabul: 12.08.2021 } \\
\text { Yayın: 24.08.2021 } \\
\text { Anahtar Kelimeler: } \\
\text { Tasarruf Finansman } \\
\text { Sözleşmesi, Faizsiz } \\
\text { Tasarruf Finansmanı, } \\
\text { Tasarruf Finansmanı, } \\
\text { Finansman Aracılik } \\
\text { Hizmetleri, İslami } \\
\text { Finansman Modeli. }\end{array}$ & 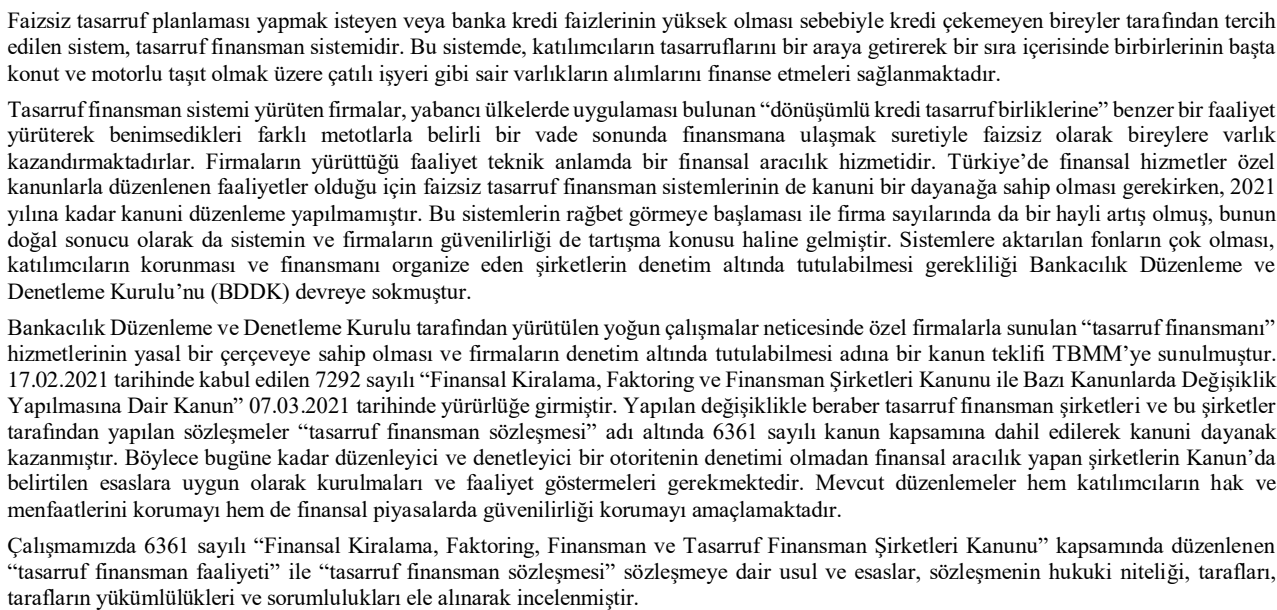 \\
\hline
\end{tabular}

\section{Savings Financing Contract}

\begin{tabular}{|c|c|}
\hline Article Info & ABSTRACT \\
\hline $\begin{array}{l}\text { Article History } \\
\text { Received: } \mathbf{1 5 . 0 5 . 2 0 2 1} \\
\text { Accepted: } \mathbf{1 2 . 0 8 . 2 0 2 1} \\
\text { Published: } \mathbf{2 4 . 0 8 . 2 0 2 1} \\
\text { Keywords: } \\
\text { Savings Financing } \\
\text { Contract, Interest- Free } \\
\text { Savings Financing, } \\
\text { Savings Financing, } \\
\text { Financial Intermediation } \\
\text { Service, Islamic Financing } \\
\text { Model. }\end{array}$ & 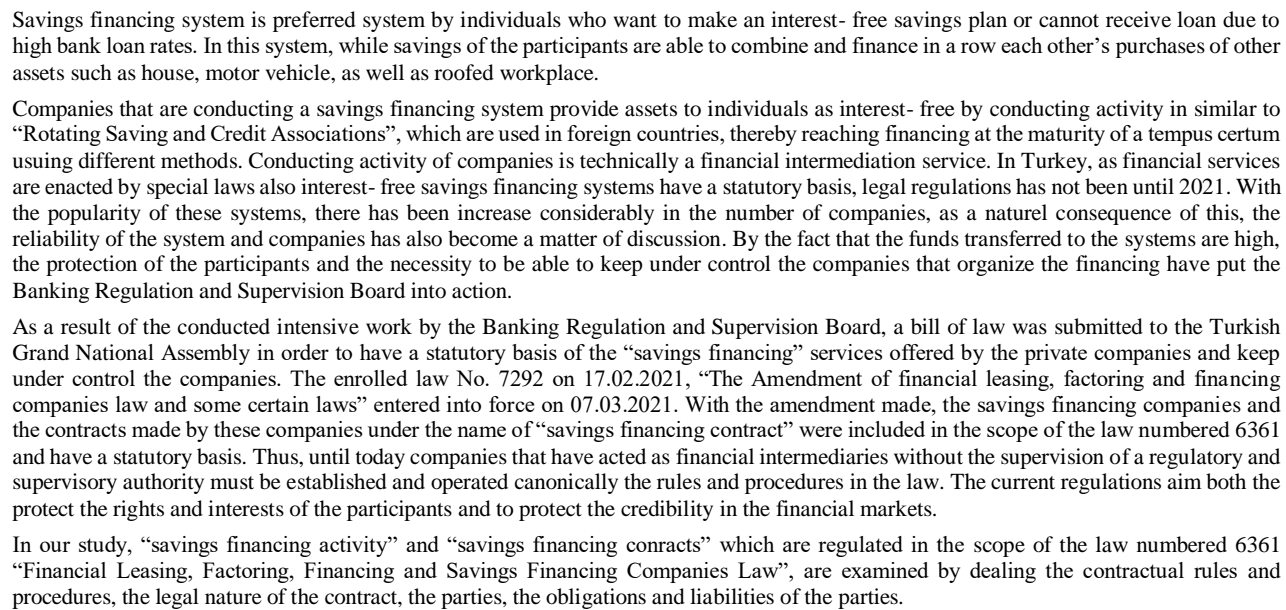 \\
\hline
\end{tabular}

Atıf/Citation: Selvi, Nurtaç Endes. (2021). Tasarruf Finansman Sözleşmesi, Necmettin Erbakan Üniversitesi Hukuk Fakültesi Dergisi, 4(2), s.441-467.

Plagiarism: Bu makale intihal programında taranmış ve en az iki hakem incelemesinden geçmiştir. // This article has been scanned via a plagiarism software and reviewed by at least two referees.

"This article is licensed under a Creative Commons Attribution-NonCommercial 4.0 International License (CC BY-NC 4.0)"

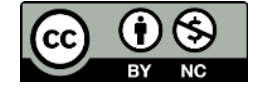

* Bu makale, 10-12 Nisan 2021 tarihinde Necmettin Erbakan Üniversitesi Hukuk Fakültesi tarafindan gerçekleştirilen Uluslararası Necmettin Erbakan Hukuk Kongresi'nde bildiri olarak sunulmuştur. 


\section{GİRiș}

Gelişen ve gelişmekte olan ülkelerde nüfusun hızla artması ile paralel olarak bireylerin temel ihtiyaçlarında da her geçen gün artış görülmektedir. Nüfus artışı, göçler, afet riski, güvenli, nitelikli, dayanıklı yerlerde yaşama isteği toplumun temel ihtiyaçlarını belirleyen parametreler olarak karşımıza çıkmaktadır. Gelir dağılımdaki adaletsizlik, ülke ekonomisinde meydana gelen gözle görülen veya görülmeyen dalgalanmalar, enflasyonun yüksek seyri elde edilen gelirle tasarruf veya yatırım yapma ihtimalini neredeyse imkansızlaştırmaktadır. Bunun sonucu olarak da bireylerin peşin alım gücü düşmektedir. Peşin alım gücünün olmaması başta konut olmak üzere, taşıt, işyeri gibi ihtiyaçların karşılanması için çeşitli finansman aracılarına başvurulma zorunluluğunu doğurmaktadır ${ }^{1}$.

Ekonomik yapının en önemli alt sistemini teşkil eden finansal sistemin temel unsurlarından biri finansal aracılardır. Finansal aracılar, tasarrufçular ile yatırımcılar arasında yer alan ve birinden diğerine fon aktarımına yardımcı olan temel mekanizmayı oluştururlar². Yatırımların finansmanında finansal sistem büyük önem arz eder, çünkü tasarruflarını değerlendirmek isteyen çok sayıdaki tasarruf sahibinin girdiği finansal piyasalarda yatırımlar bir havuzda birikmekte ve yatırım harcamalarını karşılayamayan yatırım sahiplerine kaynak temini krediler vasıtasıyla transfer edilmektedir. Finansal sistemin gelişmesi, yani sistemin hem büyümesi hem de yap1 itibariyle değişmesi, finansal derinleşme olarak da ifade edilir. Finansal derinleşmenin bir yansıması da finansal aracıların sunduğu hizmetlerin genişlemesidir. Finansal piyasaların derinlik kazanmaması ise finansal açıdan sığ ekonomilerin hâkim olduğu ülkelerde bankacılık sisteminin baskın olmasına sebep olur. Ancak gelişme devam ettikçe ve ekonomi büyüdükçe bankacılık sistemi önemini kaybetmeye başlar ${ }^{3}$. Bankacılık, konvansiyonel finansman sisteminin bir parçasıdır ve bu sistem tarafından sağlanan fonlar faize dayanmaktadır. Bu durum gelişmekte olan ülkelerde finansman maliyetlerini aşırı yükseltmekte, yüksek finansman maliyetleri de finansmana ulaşmayı zorlaştırmaktadır ${ }^{4}$.

Finansal aracılar içinde en çok tercih edilen sistem bankacılık olmakla birlikte, bankaların son yıllarda uyguladıkları yüksek faiz oranları veya bireylerin faizsiz tasarruf taleplerinin fazla olması alternatif sistemlerin doğmasına sebep olmuştur. Konvansiyonel finans sisteminin alternatifi ise faizsiz finansman kuruluşlarıdır ${ }^{5}$. Son yıllarda ülkemizde en çok tercih edilen sistem,

\footnotetext{
${ }^{1}$ Ekonomilerin tasarruf konusunda daha dikkatli olması gerekmektedir. Zira, bireylerin tüketim davranışlarındaki hızlı değişimler, ulusal kriz sayılarının artması ve küreselleşme, uluslararası krizlerin de etkilerinin hızlı bir şekilde yayılmasını sağlamaktadır. Tasarrufların arttırılması kalkınmanın ve büyümenin de temelidir. Bu konuda bkz. Özcan, Burcu/ Peker, Ayşe Esra. Özel Tasarrufun Belirleyenleri: Türkiye Örneği, Fırat Üniversitesi Sosyal Bilimler Dergisi, C. 28, S. 2, Temmuz 2018, 185, https://dergipark.org.tr/tr/pub/firatsbed/issue/39182/460935, (E.T. 15.04.2021).

2 Tuna, Abdulkadir. Finansal Ekonomi, İstanbul Üniversitesi Açık ve Uzaktan Eğitim Fakültesi, https://cdnacikogretim.istanbul.edu.tr/auzefcontent/20_21_Guz/finansal_ekonomi/2, (E.T. 21.03.2021).

3 Afşar, Aslı. Finansal Gelişme ile Ekonomik Büyüme Arasındaki İlişki, Muhasebe ve Finansman Dergisi, S. 36, 2007, 189 vd., https://dergipark.org.tr/tr/pub/mufad/issue/35607/395635, (E.T. 21.03.2021).

${ }^{4}$ Okur, M./ Çatıkkaş, Ö./ Ersoy, M.. Bir Gölge Bankacılık Uygulaması Olarak Gayrimenkul Finansmanında Alternatif Bir Faizsiz Finansman Modeli: İpoteğe Dayalı Paylaşımlı Faizsiz Finansman Modeli, Isşletme Araştırmaları Dergisi, 10/4, 2018, 391, https://www.isarder.org/2018/vol.10_issue.4_article19_full_text.pdf, (E.T. 25.03.2021).

${ }^{5}$ Okur/ Çatıkkaş / Ersoy, 391.
} 
tasarrufa dayalı faizsiz finansman sistemidir6. "İslami finansman modeli" olarak da anılan, tasarrufa dayalı faizsiz finans sistemi, geçmişi birkaç yüzyıla dayanan ve farklı şekillerde uygulanan bir sistemdir. Türkiye'deki geçmişi taşıt edindirmeye yönelik faaliyetle 90'lı yıllarda başlamış, 2000'li yıllardan itibaren de konut finansmanına yönelmiștir ${ }^{8}$. Sistemin yürütücüleri teknik anlamda finansal aracılık faaliyeti yürüten, uluslararası platformda uygulaması bulunan "dönüşümlü kredi tasarruf birliklerine" "9 benzer bir faaliyet icra eden özel firmalardır. Firmalar, müşterilerin konut, araç, işyeri gibi ihtiyaçlarını karşılamak amacıyla yapılan anlaşmaya bağlı olarak peşinat ödeyerek veya peşinatsız, faizsiz geri ödemelerle, belirli bir vade sonunda ihtiyaç duydukları finansmanın ihtiyaç sahibine temin edilmesini sağlamaktaydılar. Yürütülen finansal hizmet, 2021 yılına kadar kanuni bir düzenleme altına alınmamış, firmalar denetime tabi olmaksızın faaliyet icra etmeyi sürdürmüsslerdir. Bu süre zarfında sisteme gösterilen ilginin fazlalığı firmaların da sayısını arttırmış, sistemin ve firmaların güvenilirliği de tartışma konusu haline gelmiştir. Nihayetinde "tasarrufa dayalı faizsiz finansman sistemi”, 17.02.2021 tarihinde kabul edilen, 7292 sayılı "Finansal Kiralama, Faktoring ve Finansman Şirketleri Kanunu ile Bazı Kanunlarda Değişiklik Yapılmasına Dair Kanun"10 kapsamında 6361 sayılı "Finansal Kiralama, Faktoring ve Finansman Şirketleri Kanunu”nda yapılan değişiklikle "Tasarruf Finansman” modeli adı altında hukukumuza girmiştir.

Getirilen değişiklik ile birlikte 6361 sayılı kanunun adı "Finansal Kiralama, Faktoring, Finansman ve Tasarruf Finansman Şirketleri Kanunu" olarak değiștirilmiștir. Bunun dışında tasarrufa dayalı faizsiz finansman hizmeti veren şirketlerin unvan ve kuruluş esasına dair şartlar getirilmiş, tasarruf finansman şirketlerinin müşteriler ile yaptıkları sözleşmeler "tasarruf

\footnotetext{
${ }^{6}$ Tasarrufa dayalı finansman düşüncesinin temeli 1775 yılında İngiltere'de kurulan "Yapı tasarruf sandıkları”dır. Yapı tasarruf sandıkları kolektif dayanışma temeline dayanmaktadır. Üyelerin konut temini için ihtiyaç duydukları krediyi sağlamak ve potansiyel kredi gereksinimini karşılamak amacıyla konut sahibi olmak isteyen bireylerin belirli bir hesaba düzenli ödeme yaparak tasarruf sağlaması, hesaptaki tasarrufun belirli bir miktara ulaşması ile de kredi hakkının doğması amaçlanmıştır. Bankaya benzer faaliyet gösterseler de banka statüsünde olmayan bu sandılar Almanya'da olduğu gibi Bankacılık Denetleme Kuruluşları ile denetim altında tutulmaktadır. Bu konuda bkz. Kılıç, Selim. Konut Finansman Modeli Olarak Yapı Tasarruf Sandıkları; Almanya ve Türkiye'deki Uygulamaları, Yönetim ve Ekonomi, Celal Bayar Üniversitesi İktisadi ve İdari Bilimler Fakültesi Dergisi, C. 14, S. 1, 235 vd., https://dergipark.org.tr/tr/pub/yonveek/issue/13686/165630, (E.T. 11.04.2021); Birsin, Mehmet/ Ötegeçeli, Hatice. Tasarrufa Dayalı Faizsiz Finansman Sistemi ve F1khî Meşruiyeti Üzerinde Yapılan Değerlendirmeler, Mesned İlahiyat Araştırmaları Dergisi, C. 10, S. 1, 2019, 87 vd., https://dergipark.org.tr/tr/pub/mesned/issue/46608/584675, (E.T. 11.04.2021).

${ }^{7}$ İslami finans sistemi olarak da ifade edilen bu finans yapısı, temel prensiplerini, usul ve esaslarını İslam hukukundan almaktadır. Bu temel prensipler: Faizin yasak olması, risk, kar ve zarar paylaşımı ile belirsizlik (garar) yasağıdır. Bu konuda bkz. Karahan, Hediyatullah/ Ersoy, Hicabi. Faizsiz Finansın Temel Prensipleri ile Türkiye'de Reel Kesimde Kullanılmas1, Maliye ve Finans Yazılarl, C. 0, S. 105, 2016, 95 vd., https://dergipark.org.tr/tr/download/articlefile/302022, (E.T. 17.04.2021); Çekin, Ömer. Tasarrufa Dayall Finansman Sistemi ve İslami Finans Illkeleri Çerçevesinde Değerlendirilmesi, İstanbul Üniversitesi Sosyal Bilimler Enstitüsü, İslam İktisadı ve Finansı Anabilim Dalı, (Yayınlanmamış Yüksek Lisans Tezi), 2018, 78 vd.

${ }^{8}$ Çekin, 16 vd.; Beybur, M./Çetinkaya, M.. Tasarrufa Dayalı Faizsiz Finans Sistemine Jak Bankacılık ve Karz-1 Hasen Sistemi Önerisi, The Journal of Social Science, C: 5, S: 9, 2021, (DOI: 10.30520/tjsosci.880196, E.T. 25.03.2021); Okur/ Çatıkkaş / Ersoy, 393; Birsin/ Ötegeçeli, 89.

${ }^{9}$ Dönüşümlü kredi tasarruf birlikleri, sözleşmeye dayalı tasarruf sistemi temeline dayanmaktadır. Sözleşmeye dayalı tasarruf (contractual savings) tasarruf sahibinin belirli bir dönem birikim yaptıktan sonra önceden belirlenmiş olan menfaate ulaştı̆̆1 bir sistemdir. Bkz. Akbulak, Yavuz. Türk Finans Hukukunda Yeni Bir Kurum: "Tasarruf Finansman", Legal Blog, 2021, 2, https://legal.com.tr/blog/genel/turk-finans-hukukunda-yeni-bir-kurum-tasarruffinansman, (E.T. 09.04.2021).

${ }^{10}$ R.G. 31416, 07.03.2021.
} 
finansman sözleşmesi” adı altında tanımlanarak genel esasları belirlenmiş, şirketlerin faaliyetleri ${ }^{11}$ ve yapabilecekleri işlemler sınırlandırılmış, şirketler ve yürütülen tasarruf finansman hizmeti BDDK'nın denetimine tabi tutulmuş ve öngörülen esaslara aykırı faaliyet yürütülmesi yaptırımla müeyyidelendirilmiştir.

Çalışmamızda mevcut değişikliklerle 6361 sayılı Kanun'a yeni bir müessese olarak işlenen tasarruf finansman sözleşmesinin konusu, hukuki niteliği, unsurları, tarafların borçları ve sona ermesi genel hatları ile ele alınmış, mevcut durum itibariyle karşılaşılabilecek muhtelif uyuşmazlıklara dair kısa tespit ve değerlendirmeler yapılmıştır.

\section{Tasarruf Finansman Sözleşmesinin Tanımı ve Unsurları}

Tasarruf finansman sözleşmesi 6361 sayılı Kanun'un 39/A hükmünde 5 fikra altında düzenlenmiştir. Kanun'un yürürlüğe girmesinin akabinde BDDK tarafından "Tasarruf Finansman Şirketlerinin Kuruluş ve Faaliyet Esasları Hakkında Yönetmelik" taslağ 1 hazırlanarak görüşe açılmış, söz konusu Yönetmelik 07.04.2021 tarih 31447 sayılı Resmi Gazete'de yayımlanarak yürürlüğe girmiştir. Yönetmelikte tasarruf finansman sözleşmesine ve müşteri haklarına dair detaylı düzenlemelere de yer verilmiştir.

Tasarruf finansman sözleşmesinin amacı, konut, çatılı işyeri veya taşıt edinimi için finansman ihtiyacı duyan müşteriye tasarruf finansman şirketi vasıtasıyla faizsiz finansman esaslarına göre finansman temini sağlamaktır. Şirketler, temel olarak belirli bir malvarlığının satılmasından ziyade müşterilerin satın almak istedikleri varlık için finansman sağlamaktadırlar. Tasarruf etme ve finansman sağlama olmak üzere iki aşamadan ${ }^{12}$ oluşan sistemde bireysel tasarruf veya çekilişli grup tasarrufu imkânı sunulmaktadır. Bireysel tasarrufta müşteriler sözleşmede kararlaştırılan finansman karşılığında belirli bir vadeye kadar para yatırmakta, grup tasarrufunda ise peşinatlı veya peşinatsız olarak müşterilerin ödeme planlarına göre oluşturulan gruplar arası çekiliş yapılmak suretiyle tasarruf edecekleri dönem belirlenmektedir. Tahsisat ödemesi ${ }^{13}$ yapıldıktan sonra finansman tarihi itibariyle finansman dönemi için geri ödemeler tamamlanana kadar finanse edilen varlıkların karşılığında rehin veya ipotek teminatı istenmektedir. Şirketlerin müşterilerle yapacakları sözleşmelerin genel esaslar1 ${ }^{14}$, sözleşmede yer alacak unsurlar şirketler tarafından uygulamaya konulmadan önce hazırlanan ve BDDK'nın onayını alan içerikteki Yönetmelik'in 15. maddesinde öngörülen “genel faaliyet ilkeleri dokümanı”na göre belirlenecektir.

\footnotetext{
${ }^{11} 6361$ say1lı Kanun m. 3/1-1’ye göre “tasarruf finansman faaliyeti, bir sözleşme kapsamında önceden belirlenmiş koşulların gerçekleşmesi şartıyla konut, çatılı iş yeri veya taşıt edinimi için faizsiz finansman esaslarına göre belirli bir süre tasarruf edilmesi, müşterilere finansman kullandırllması ve toplanan tasarrufların yönetimidir".

12 Kanunda ve Yönetmelik'te söz konusu aşamalar "tasarruf dönemi” ve "finansman dönemi” olarak ifade edilmektedir.

${ }^{13} 6361$ sayılı Kanun m. 3/1-l’ye göre tahsisat, “Tasarruf finansman sözleşmesi uyarınca, tahsisata hak kazanılmasına ilişkin koşulların yerine gelmesi şartı ile müşterinin tasarruf birikimlerinin ve sözleşme kapsamında taahhüt edilen finansman tutarının müşterinin, mirasçısının veya vekilinin konut, çatılı iş yeri veya taşıt edinmesi amacıyla satıcı konumundaki üçüncü kişilere hesaben ödenmesi"dir.

${ }^{14} \mathrm{Bu}$ kapsamda müşterinin biriktirmesi gereken toplam tasarruf tutarı, tasarruf döneminden sonra hak kazanılacak finansman miktarı, organizasyon ücreti ve masraflar ile varsa sözleşme kapsamındaki diğer getiri ve maliyetlere ilişkin hesaplama yöntemleri genel faaliyet ilkeleri dokümanına göre sözleşmede belirlenmesi gereken hususlardır.
} 
Kanun'un 39/A maddesinin birinci fikrasında tasarruf finansman sözleşmesi, "belirli bir tasarruf tutarl ve dönemine bağll olarak önceden belirlenmiş koşulların gerçekleşmesi şartıyla konut, çatılı iş yeri veya taşıt edinimi için müşteriye finansman kullanma hakkı veren, şirkete ise müş̧teriye ait birikmiş tasarruf tutarını yönetme, geri ödeme ve finansman kullandırma yükümlülüğ̈̈ ile organizasyon ücreti alma hakk veren, faizsiz finansman esaslarına göre düzenlenen sözleşme" olarak tanımlanmaktadır. Tanıma göre tasarruf finansman sözleşmesinin iki tarafı vardır. Bunlar, tasarruf finansman şirketi ${ }^{15}$ ve finansman ihtiyacı olan müşteridir ${ }^{16} . \mathrm{Bu}$ ilişkiye müşterinin satın almak istediği edinimin satıcısı taraf değildir ${ }^{17}$. Müşteri tanımına Kanun'da yer verilmemiştir. Yönetmelik'in tanımlar başlığını taşıyan 3/1-g maddesine göre müşteri, tasarruf finansman sözleşmesini imzalayan gerçek veya tüzel kişidir.

Kanun'un 39/A, f. 5 ve Yönetmelik'in 16/4. maddelerinde tasarruf finansman sözleşmesinde asgari olarak bulunması gereken unsurlar sayılmıştır. Buna göre; "Konut, çatılı işyeri veya taşıt olarak belirlenmiş finansman konusuna, tutarlara (sözleşmenin tutarı, asgari tasarruf oranl, finansman tutarl, varsa finansman maliyeti ve toplam geri ödeme tutart), vadeye (tasarruf dönemi ile finansman dönemi vadeleri, öngörülen tahsisat tarihi ve finansman geri ödeme tarihleri), finansman tarihi itibartyla finansman dönemi için talep edilmesi öngörülen teminatlara, organizasyon ücretine, (varsa) tasarruf dönemi için müşteriye sağlanacak getiriye, gelir, maliyet ve masraflara, konut, çatılı iş yeri veya taşıt edinimine yönelik tasarruf etme ve finansman kullandırma dönem ve koşullarına, iade süre ve şartlarına, temerrüde, cayma hakkının kullanımına, sözleşmenin sona ermesine, feshine, mirasçılara intikaline, üçüncü taraflara devrine, tarafların hak ve yükümlülüklerine ilişkin hükümlere" sözleşmede yer verilmelidir.

Tasarruf finansman sözleşmesinin Kanun'da yapılan tanımından çıkarılabileceğimiz başlıca objektif esaslı unsurlar şunlardır: Konut, çatılı işyeri veya taşıt edinmeye yönelik faizsiz finansman sağlanması, şirketin müşteriye ait birikmiş tasarruf tutarını yönetmesi, müşterinin aldığı finansmanı belirli bir ödeme planı çerçevesinde geri ödemesi, şirketin organizasyon ücreti alma hakk1.

\footnotetext{
15 Tasarruf finansman şirketleri, Kanun'un 4 vd. maddelerinde belirtilen esaslara göre kurulmuş, en az yüz milyon Türk lirası ödenmiş sermayesi olan anonim şirketlerdir.

${ }^{16}$ Her ne kadar Kanun'un 39/A maddesinde tasarruf finansman sözleşmesinin tarafi olarak finansman temini için şirkete müracaat eden gerçek veya tüzel kişiler müşteri olarak ifade ediliyorsa da ileride açıklandığ üzere tasarruf finansman şirketi ile müşteri arasında kurulan ilişkinin (tasarruf finansman şirketleri ile tacirler arasında kurulan ticari amaçlı sözleşmeler hariç) temel olarak bir tüketici ilişkisi olması sebebiyle müşterilerin tüketici olarak düşünülmesi gerekmektedir.

17 Kanun'un 3/1-k maddesinde yapılan tahsisat tanımında müşterinin hak kazandığı tahsisat kapsamında tasarruf birikimlerinin ve şirket tarafından taahhüt edilen finansman tutarının satıcı konumundaki üçüncü kişilere hesaben ödeneceği öngörülmekte ise de bu durum satıcı tasarruf finansmanı ilişkisinin tarafı haline getirmez. Şirket, müşterinin ihtiyacı olan varlığın satıcısı ile bir sözleşme ilişkisi içinde değildir. Müşteri, satıcıya kendi ulaşmakta, gerekli incelemeler sonucunda tahsisat ödemesine aykırı bir durum tespit edilmediği takdirde alıcı (müşteri) ile satıcı arasında devir işlemleri gerçekleştirilirken şirket ödemeyi müşteri adına ve hesabına satıcıya yapmaktadır. Uygulamadaki diğer finansman sözleşmelerinde finansman şirketi, satıcı ve alıcı arasında üçlü bir ilişki mevcuttur. Zira, şirket önceden satıcı ile alıcıya sağlanacak kredinin esas ve usullerini içeren genel bir sözleşme yapmaktadır. Alıcı bu sözleşmeye taraf olmamakla beraber alıcının şirketle yapacağı finansman sözleşmesinin ve ihtiyacı olan mal veya hizmeti temin edebilmesinin ön şartı şirket ve satıcı arasındaki çerçeve sözleşmenin varlığıdır. Finansman sözleşmesine dair açıklamalar için bkz. Yavuz, Cevdet. Borçlar Hukuku Dersleri (Özel Hükümler), 13. B., İstanbul 2014, 453.
} 


\section{A. Konut, Çatılı İşyeri veya Taşıt Edinmeye Yönelik Faizsiz Finansman Sağlanması}

$\mathrm{Bu}$ unsura göre müşteri, şirkete sadece konut, çatılı işyeri veya taşıt edinimi sebebiyle finansman başvurusunda bulunabilmektedir. Bu bakımdan sözleşmenin konusunu, müşterinin ihtiyacını karşılamak için ihtiyaç duyduğu konutu, çatılı işyerini veya taşıtı edinmesi amacına yönelik sözleşmede kararlaştırılan finansmanın şirket tarafından temin edilmesi oluşturmaktadır. Kanun'daki mevcut düzenleme ile sözleşmenin ve tasarruf finansman faaliyetinin konusunun da konut, çatılı işyeri veya taşıt olmak üzere sınırlandırıldığı görülmektedir. Müşteri bu edinimler dışında başka bir varlık edinimi için veya bir varlık edinimi göstermeksizin doğrudan finansman desteği için şirkete başvuramayacaktır ${ }^{18}$. Bu noktada sistemi sektördeki diğer uygulamalardan ayıran en temel unsurlardan biri şirketten temin edilecek finansmanın tasarruf etme şartına bağlı olmasıdır. Şirket, müşterinin finansman ihtiyacı olan varlı̆̆ı bulması kaydıyla müşteriye finansman teslimini gerçekleştirmektedir.

Şirket, müşterinin ihtiyacı olan finansmanı sözleşmede belirlenmiş olan tasarruf tutarı ve tasarruf dönemine bağlı olarak önceden belirlenmiş koşulların gerçekleşmesi şartıyla temin edecektir. Söz konusu şartlar, Yönetmelik'in 15. maddesinde öngörülen “genel faaliyet ilkeleri dokümanında" sözleşme kapsamına dair belirlenen genel çerçeveye uygun olarak tespit edilmiş esaslardır. $\mathrm{Bu}$ esaslardan biri de sözleşmenin faizsiz finansman esaslarına göre düzenlenmiş olmasidir.

\section{B. Şirketin Müşteriye Ait Birikmiş Tasarruf Tutarını Yönetmesi}

Müşterinin şirketle akdettiği tasarruf finansman sözleşmesi gereğince tahsisat ödenene kadar müşteri tarafindan yapılan tasarruf ödemeleri tasarruf fon havuzunda toplanmaktadır. Tasarruf fon havuzu, Kanun'un 3/1-m maddesinde “belirli bir dönemde tasarruf finansman şirketi nezdindeki birikmiş tasarruflar ve finansman geri ödemelerinden oluşan tutarlar toplamından, tahsisat olarak verilmiş tutarlar ile tasarruf geri ödemelerinin düşülmesinden sonra kalan tutar" olarak tanımlanmaktadır. Fon havuzunda biriken yatırımlar şirketin kendi hesaplarından ayrıdır. Şirket, tasarruf fon havuzunda birikmiş müşterilere ait tasarrufları Kanun'un 39/B ve Yönetmelik'in 23. maddelerine göre faizsiz yatırım araçları $^{19}$ ile yönetmelidir. Yatırımların yönetilmesi neticesinde elde edilen getiri, sözleşmede yatırılan tasarrufların müşteriye getiri sağlaması öngörülmüş olmak kaydıyla müşterilerin tasarruf birikimlerine ilave edilir. Sözleşmede

\footnotetext{
${ }^{18}$ Düzenleme öncesi dönemde bazı şirketlerin müşterilerin arazi ihtiyaçlarını tedarik etmek için finansman sağladıkları ve hatta edinim karşılığı olmaksızın doğrudan finansman desteği sağlayan uygulamalara başvurarak "gölge bankacıllk" faaliyeti icra eder bir mahiyet arz ettikleri görülmekteydi. Bu sebeple tasarruf finansman sözleşmelerinin konusunu sınırlayan mevcut düzenlemenin tasarruf finansman faaliyetinin yeknesaklığı, sistemin güvenilirliği ve denetimi açısından da yerinde olduğu kanaatindeyiz. Yönetmelik'in müşteri haklarını düzenleyen 17/7 maddesinde şirketlerin, müşterilerden tasarruf dönemine dair (finansman teslimi gerçekleştirene kadar geçen süre) ipotek, rehin veya senet gibi teminatların istenmesi yasaklanmıştır. Bu düzenlemenin ileride de açıkladığımız üzere müşteri lehine getirilen cayma hakkı ve fesih hakkına dair düzenlemelerle de uyumlu ve yerinde olduğu kanaatindeyiz. (Tasarrufa dayalı faizsiz finansman sisteminin gölge bankacılık faaliyeti olduğuna dair bilgiler için bkz. Okur/ Çatıkkaş / Ersoy, 391 vd.).

19 Yönetmelik'in 23/2 hükmüne göre birikmiş tasarrufların yönetiminde tasarrufların değerlenmesi için başvurulabilecek araçlar, "Hazine ve Maliye Bakanlığının ihraç etmiş olduğu yurt içi kira sertifikalarının alınması, Türkiye'de faaliyet gösteren katılım bankalarında açılacak vadeli ve vadesiz katılma hesapları, Türkiye'de faaliyet gösteren varlık kiralama şirketleri tarafindan ihraç edilen yurt içi kira sertifikalarının alımı ve Kurulca uygun görülecek diğer faizsiz yatırım araçları"dır.
} 
müşteriye getiri ödemesi yapılacağı kararlaştırılmamışsa getiriler tasarruf fonu içinde ihtiyat fonu olarak ayrilır.

\section{Müşterinin Aldığı Finansmanı Belirli Bir Ödeme Planı Çerçevesinde Geri Ödemesi}

Tasarruf finansman sözleşmesinin asgari unsurlarından biri de müşterinin aldığı/ alacağı tahsisat karşılı̆̆ geri ödemede bulunacağı tutardır. Müşteri, konut, işyeri veya taşıt edinimi amacıyla şirketten aldığı yüksek miktarlı finansmanı sözleşmede kararlaştırılan belirli bir ödeme planı çerçevesinde uzun vadeye yayılmış olarak geri ödemeyi borçlanmaktadır. Sözleşmede kararlaştırılacak olan vadeler Yönetmelik'in 22/3 hükmüne göre konut ve çatılı işyeri sözleşmeleri için yüz yirmi ayı, taşıt için altmış ayı geçemez. Müşteri tarafından yapılacak geri ödemeler de tasarruf fon havuzunda toplanmaktadır.

\section{D. Şirketin Organizasyon Ücreti Alma Hakkı}

Sözleşmenin tanımından da açıkça anlaşıldığı üzere şirket, müşteri adına yürüttüğü tasarruf faaliyetleri kapsamında ve tasarruf fon havuzunun yönetimi karşılığında organizasyon ücreti alma hakkına sahiptir. Kanun'un 39/A, f. 5 ve Yönetmelik'in 16/4-f hükümlerine göre tasarruf finansman sözleşmesinin asgari unsurlarından biri de organizasyon ücretidir. Taraflar sözleşme kapsamında şirketin yürüteceği finansman faaliyeti kapsamında alacağı ücreti kararlaştırmak zorundadırlar. Yönetmelik'in 17/7. maddesine göre şirket bu ücret dışında müşteriyi ödeme yükümlülüğü altına sokacak başka bir talepte bulunamaz. Sözleşmenin kapsamını belirleyen tüm unsurlarda olduğu gibi sözleşmede müşteriye sunulan organizasyon ücreti ile ilgili hükümlerde “genel faaliyet ilkeleri dokümanında" Kurum'un onayladığı esaslara uygun olmak zorundadır.

\section{TASARRUF FINANSMAN SÖZLEŞMESINIIN HUKUKİ NITTELİ̆İ VE ŞEKLİ}

Yönetmelik'in tasarruf finansman sözleşmesini düzenleyen 16/2 maddesinde de açıkça ifade edildiği üzere tasarruf finansman sözleşmeleri, BDDK'nın uygun görüşü alınarak Finansal Kurumlar Birliği tarafından belirlenen bir çerçeve sözleşmedir. Müşteri, şirket tarafından Kanun ve Yönetmelik'te açıkça belirtilmiş asgari unsurları içeren, BDDK tarafından onaylanmış "genel faaliyet ilkeleri dokümanında" öngörülen sözleşme kapsamına uygun hazırlanmış ana esaslar çerçevesinde finansman sağlamak hususunda şirketle anlaşmaya varır. Tarafların sözleşmenin tüm esaslı noktalarında karşılıklı rızalarının uyuşması gereklidir. Bu bakımdan tasarruf finansman sözleşmesi rızai bir sözleşmedir. Sözleşmede hem şirket hem müşteri alacaklı ve borçlu sıfatlarına sahiptir. Bu sebeple iki tarafa borç yükleyen borçlandırıcı bir sözleşme niteliğindedir. Müşterinin, alacağ1 tahsisatı geri ödemeyi borçlanması ve bunu uzun vadelere yayılmış olarak ifa edecek olması sebebiyle tasarruf finansman sözleşmesi sürekli edimli ve ivazlı bir sözleşmedir ${ }^{20}$.

\footnotetext{
${ }^{20}$ Sürekli borç ilişkisi, taraflardan birinin asli edim yükümlülüğünü uzunca bir süreye yayılmış, belirli veya belirsiz bir zaman dilimi içinde ifa etmeyi üstlendiği sözleşmelerdir. Borç ilişkisinin sürekli olup olmadığının tespitinde esas alınan kıstas, borçlu edimini bir defa ifa ettiğinde alacaklının menfaatinin o anda mı yoksa zaman içinde mi gerçekleştiğidir. Borçlunun üstlendiği olumlu, yapma edimleri uzun bir zaman içinde yerine getiriliyorsa (burada zaman yönünden hiçbir kesintiye uğramaması anlaşılmamalıdır) borçlunun edimi sürekli edimdir. Eren, Fikret. Borçlar Hukuku Genel Hükümler, 4. B., Ankara 2017, 107; Akınc1, Şahin. Borçlar Hukuku Bilgisi, 11.B., Konya 2020, 27; Antalya, Gökhan. Borçlar Hukuku Genel Hükümler Cilt. V/1, 1, 2.B., Ankara 2019, 103 vd.; Tekinay, Selahattin Sulhi/ Akman, Sermet/ Burcuoğlu, Haluk/ Altop, Atilla. Borçlar Hukuku Genel Hükümler, 7. B., İstanbul, 1993, 10, 11; Seliçi, Özer. Sözleşmeden Doğan Sürekli Borç İlişkilerinin Sona Ermesi, İstanbul 1977, 8 vd.; Kuntalp,
} 
Önceki açıklamalarımızda da ifade ettiğimiz üzere tasarruf finansman sözleşmesine ilişkin kanuni düzenlemeler 07.03.2021 tarihi itibariyle yürürlüğe girmiştir. 2021 yılı öncesinde herhangi bir kanuni düzenlemeye tabi olmaması sebebiyle tasarrufa dayalı faizsiz finansman sözleşmelerinin isimsiz (karma) sözleşme olarak değerlendirilmesi söz konusu iken, mevcut haliyle 6361 sayılı Kanun'da düzenlenmiş “tasarruf finansman sözleşmesi” tipik- isimli bir sözleşme niteliği kazanmıştır ${ }^{21}$.

Kanun'da tasarruf finansmanı sözleşmesi kapsamında finansman kullanacak olan kişiler müşteri olarak ifade edilmiş olsa da bu gerçek veya tüzel kişilerin (ticari amaçla hareket edenler hariç) aslında tüketici sıfatına haiz olduğu gözden kaçırılmamalıdır. 6502 sayılı Tüketicinin Korunması Hakkında Kanun (TKHK) m. 3/1-k hükmüne göre "tüketici; ticari veya mesleki olmayan amaçlarla hareket eden gerçek veya tüzel kişidir”. Tasarruf finansman sözleşmesinde de Yönetmelik'in m. 3/1-r hükmünde tanımlanan ticari amaçlı sözleşmeler, yani ticari amaçla hareket eden ticari işletmeleriyle ilgili finansman kullanan gerçek veya tüzel kişiler hariç, diğer gerçek veya tüzel kişilerin tüketici hükümlerine göre değerlendirilmeleri gerekmektedir. Diğer yandan TKHK. m. 3/1-1 hükmüne göre "sağlayıcı, kamu tüzel kişileri de dahil olmak üzere ticari veya mesleki amaçlarla tüketiciye hizmet sunan ya da hizmet sunanın adına ya da hesabına hareket eden gerçek veya tüzel kişiyi” ifade eder. Aynı Kanun'un 3/1-d maddesinde de hizmet, "bir ücret veya menfaat karşıllı̆̆nda yapılan ya da yapılması taahhüt edilen mal sağlama dışındaki her türlü tüketici işleminin konusu" olarak tanımlanmıştır. Tasarruf finansman şirketleri de müşteriye ticari ve mesleki amaçlarla finansman sağlama ve müşterinin biriken tasarrufunu yönetme hizmeti sunmaktadır. $\mathrm{Bu}$ nedenle TKHK hükümlerine göre tasarruf finansman şirketleri de sağlayıcı sıfatındadır. Aynı Kanun'un 3/1-1 hükmüne göre "Tüketici işlemi, mal veya hizmet piyasalarında kamu tüzel kişileri de dâhil olmak üzere ticari veya mesleki amaçlarla hareket eden veya onun adına ya da hesabına hareket eden gerçek veya tüzel kişiler ile tüketiciler arasında kurulan, eser, taşıma, simsarlık, sigorta, vekâlet, bankacılık ve benzeri sözleşmeler de dâhil olmak üzere her türlü sözleşme ve hukuki işlemi" ifade eder. Bu tanıma göre tüketici işleminin kapsamı oldukça geniş tutulmuştur ve burada önemli olan işlemin niteliğinden ziyade tarafların sıfatıdır.

Yönetmelik'in 16/4-n maddesinde sözleşmeden doğan uyuşmazlıkları çözecek yetkili tüketici hakem heyetinin veya mahkemenin sözleşmenin asgari unsurları içinde belirlenmesi gerektiğine dair hüküm de uyuşmazlık çözüm mercii olarak tüketici hakem heyetini veya mahkemesini yetkili göstererek tasarruf finansman sözleşmesinde şartları dahilinde müşteri ve şirket arasındaki ilişkinin tüketici ilişkisi olarak değerlendirileceğini teyit eder mahiyettedir.

Tasarruf finansman sözleşmeleri her ne kadar her müşteriye ait ayrı ödeme planları yapılmak suretiyle tarafların üzerinde görüşüp mutabakata vardıkları bir sözleşme olsa da yapılan sözleşme genel işlem koşulları içeren de bir sözleşmedir. Zira, sözleşme hükümlerinin birçoğu önceden BDDK'nın onayını almış ve şirket tarafından akdedilecek bütün sözleşmelerde kullanılacak olan hükümlerdir, bu hükümlerin müşterilerin sübjektif durumlarına göre değiştirilmesi mümkün değildir. Bu sebeple söz konusu sözleşme ilişkisinin TBK. m. 20 vd. hükümleri çerçevesinde denetimlerinin yapılması gerekmektedir. Ayrıca TKHK. m. 5’te “haksız

Erden. Ard arda Teslimli Satım Akdi, Ankara 1968, 18; Von Thur, Andreas. (Çev. Cevat Edege), Borçlar Hukuku, C. 1, İstanbul 1952, 50; Altık Ormancı, Pınar. Sürekli Borç İlişkilerinin Haklı Sebeple Feshi, İstanbul 2011,20 vd.

${ }^{21}$ Eren, 17; Akıncı, 64 vd.; Antalya, 127 vd.. 
şartlar" düzenlenmiştir. Tüm bu düzenlemeler tasarruf finansman sözleşmesi açısından ele alındığında, şirket ve müşteri arasında tüketici ilişkisinin kurulduğu hallerde öncelikle TKHK hükümleri kapsamında sözleşmedeki müşteri aleyhine olan hükümlerin haksız şart açısından değerlendirilmesi gerekecek, TKHK hükümlerinin yetersiz olduğu hallerde TBK hükümleri uygulanabilecektir.

Sonuç olarak söz konusu düzenlemeler göstermektedir ki, müşteri ile şirket arasındaki tasarruf finansman sözleşmesinin büyük bir çoğunluğu (sağlayıcı ve tüketici sıfatını taşıyan taraflar için) tüketici sözleşmesidir. Kanaatimizce, ticari amaçlı sözleşmeler hariç diğer müşterileri de tüketici saymak gerekir ${ }^{22}$. Ticari amaçlı sözleşmeler hariç diğer gerçek ve tüzel kişi müşteriler tüketici, şirketle bu kişiler arasındaki işlem ise tüketici işlemi olduğuna göre taraflar arasındaki ilişki TKHK hükümlerine de tâbidir. Özel kanun olan TKHK'na göre 6361 say1lı Kanun ve buna ilişkin düzenlenmiş olan ilgili yönetmelik hükümleri tasarruf finansman faaliyeti için daha özel bir düzenlemedir. Bu sebeple öncelikle 6361 sayılı Kanun ve ilgili Yönetmelik'in (her iki kanuna da aykırı olmamak kaydıyla) emredici hükümlerinin, bu düzenlemelerde saklı tutulan veya hüküm bulunmayan hallerde de TKHK hükümlerinin kıyasen uygulanması gerekecektir.

Tasarruf finansman sözleşmenin şekli hususunda ise 6361 sayılı Kanun'un 39/A, f. 2 maddesine göre "tasarruf finansman sözleşmesinin yazllı veya uzaktan iletişim araçlarının kullanılması suretiyle mesafeli olarak ya da mesafeli olsun olmasin Kurulun yazılı şeklin yerine geçebileceğini belirlediği ve bir bilişim veya elektronik haberleşme cihazı üzerinden gerçekleştirilecek ve müşteri kimliğinin doğrulanmasına imkân verecek yöntemler yoluyla kurulacak şekilde düzenlenir olarak yapılması gerekir". Kanun, yazılı şekil şartını benimsemekle beraber Yönetmelik'te şekil şartının detaylarına ve maddede zikredilen hazır olmayanlar arası mesafeli sözleşme görüşmeleri için Kurul'un belirlemesi gereken yazılı şekil yerine geçecek usul ve esaslara dair bir düzenleme getirilmemiştir. Bu durumda tasarruf finansman sözleşmesinde yazılı şekil şartı esastır. Ancak BDDK'nın yapacağı düzenlemeler neticesinde yazılı şekil yerine geçecek yöntemlerle de sözleşme yapılabilecektir. Bu durumda mevcut düzenleme tasarruf finansman sözleşmesinin şekli hususunda üç alternatif usul öngörmektedir. Bunlar: Yazılı şekil, uzaktan iletişim araçlarının kullanılması suretiyle yazılı olarak ve mesafeli olsun veya olmasın Kurulun yazılı şekil yerine geçebileceğini belirlediği ve bir bilişim veya elektronik haberleşme cihazı üzerinden gerçekleştirilecek ve müşteri kimliğinin doğrulanmasına imkân verecek yöntemlerdir ${ }^{23}$. Mevzuatta tasarruf finansman sözleşmesinin taraflarca uzaktan iletişim araçlarıyla ya da yazılı şekil yerine geçecek usullerle veya elektronik ortamda yapılması halinde uygulanacak usul ve esasların neler olduğu hususuna dair belirsizlik de BDDK'nın 07.05.2021 tarihinde yayımladığı "Finansal Kiralama, Faktoring, Finansman ve Tasarruf Finansman Şirketlerince Kullanılacak Uzaktan Kimlik Tespiti Yöntemlerine ve Elektronik Ortamda Sözleşme İlişkisinin Kurulmasına İlişkin Yönetmelik Taslağı” ile giderilmiş oldu. Taslağın 1. maddesine göre

\footnotetext{
${ }^{22}$ Çalışmamızda tasarruf finansman sözleşmesi sadece tüketici hukuku açısından değil genel hatları itibariyle ele alınmış olduğundan bundan sonraki açıklamalarımızda tasarruf finansman sözleşmelerinin ticari amaçlı sözleşmeleri kapsaması sebebiyle "müşteri” kavramı kullanılmaya devam edilmiştir.

23 Şekil şartına dair mevcut düzenleme sadece tasarruf finansman sözleşmeleri için değil, aynı zamanda 18.06.2020 tarihli 7247 sayılı Kanun ile yapılan değişiklik neticesinde 5411 sayılı Bankacılık Kanunu, 5464 sayılı Banka Kartları ve Kredi Kartları Kanunu, 6362 sayılı Sermaye Piyasası Kanunu, 6493 sayılı Kanun ve 6361 sayılı Kanun kapsamındaki finansal kiralama, faktöring, finansman sözleşmeleri için de getirilmiştir.
} 
Yönetmelik ile "uzaktan kimlik tespiti yöntemlerine ve müşteri kimliğinin tespit edilmesini müteakip sunulacak hizmetlere yönelik olarak mesafeli olsun olmasın bir bilişim veya elektronik haberleşme cihazı üzerinden yazılı şeklin yerine geçecek şekilde ya da mesafeli olarak sözleşme ilişkisinin kurulmasına yönelik usul ve esasların düzenlenmesi” amaçlanmıştır. Taslağın yürürlük hükmünü düzenleyen 14. maddesine göre Yönetmelik yayımı tarihinde yürürlüğe girecektir. Bu durumda 6361 sayılı Kanun'un geçici 2. maddesinde göre 6 aylık intibak sürecinde olan şirketlerin yeni düzenlemelere göre gerekli alt yapıyı kurabilmeleri açısından söz konusu Yönetmeliğin en kısa zamanda yürürlüğe girmesi gerektiği kanaatindeyiz.

Üzerinde durulması gereken bir diğer husus, şirket ve müşteriler arasında akdedilecek tasarruf finansman sözleşmesinde yazılı şeklin uygulanacağı durumlarda ticari veya mesleki amaçla hareket etmeyen gerçek veya tüzel kişi müşterilerle kurulan sözleşme ilişkisinin bir tüketici ilişkisi olduğu göz önünde bulundurularak TKHK' da öngörülen yazılı şekil esaslarına da riayet edilmesi gerektiğidir. TKHK'nın 4/1 hükmüne göre, “Bu Kanunda yazılı olarak düzenlenmesi öngörülen sözleşmeler ile bilgilendirmeler en az on iki punto büyüklüğünde, anlaşılabilir bir dilde, açık, sade ve okunabilir bir şekilde düzenlenir ve bunların bir nüshası kâğı üzerinde veya kalıcı veri saklayıcısı ile tüketiciye verilir". Diğer yandan, Yönetmelik'in müșteri haklarını düzenleyen 17/5 maddesindeki "şirketin sözleşmenin bir nüshasının müşteriye teslim etmesi” yönündeki düzenleme de TKHK m. 4/1 hükmü ile örtüşmektedir. TKHK. m. 4/1'e göre tüketici sözleşmelerin yazılı şekilde yapılması gerektiği ifade edilse de mesafeli sözleşmelerde veya uzaktan iletişim araçlarının kullanıldığı tüketici sözleşmelerinde de yazılı şekil dışında yöntemlere başvurulması söz konusu olacaktır. Keza TKHK. m. 4/4'te "tüketiciden talep edilecek her türlü ücret ve masrafa ilişkin bilgilerin, uzaktan iletişim aracıyla kurulan sözleşmelerde kullanılan uzaktan iletişim aracına uygun şekilde verilmesi gerektiği, bu bilgilerin tüketiciye verildiğinin ispatının sözleşmeyi düzenleyene ait olduğu" düzenlenmiştir. Bu düzenlemeler göstermektedir ki, her ne kadar tüketici sözleşmelerinde esas olan şekil şartı yazılı şekilse de mesafeli sözleşmeler gibi tüketici sözleşmelerinin de uzaktan iletişim araçlarının kullanılması suretiyle kurulması mümkündür. Tasarruf finansman sözleşmelerinin şirket ve tüketici sıfatına sahip müşteriler ile gerçekleştireceği yazılı şekil yerine geçecek yöntemlerinin kullanıldığı sözleşmelere 07.05.2021 tarihinde yayımlanan Yönetmelik taslağının yürürlüğe girmesi ile tasarruf finansman sözleşmelerinde özel hüküm teşkil edeceği için öncelikle Yönetmelik hükümlerinin uygulanması gerekecektir. Ancak mevcut düzenlemelerde bir boşluk bulunması veya yürürlüğe girecek Yönetmelikteki hükümlerin mevcut bir uyuşmazlığı çözmekte yetersiz kalması halinde TKHK'un bu hususa dair özel hükümlerine (özellikle finansal hizmete ilişkin mesafeli sözleşmelere ilişkin) uygun düştüğü ölçüde başvurulabilecektir.

Tasarruf finansman sözleşmesinin yazılı olması bir geçerlilik şartıdır. Bu şartın yerine getirilmemiş olması veya maddede zikredilen Kurul tarafından belirlenecek olan yazılı şekil yerine geçebilecek usullere aykırı olan sözleşmeler kesin hükümsüz sayılacaktır. Ancak burada özellikle üzerinde durulması gereken bir husus, (bilhassa, sözleşmenin yazılı şekil yerine geçecek usulde yapılması halinde) şirketin sözleşmenin şekil yönünden geçersizliğini müşteri aleyhine ileri sürüp süremeyeceğidir. Tasarruf finansman sözleşmesi bir çerçeve sözleşmedir ve Kurul'un onay verdiği ilkelere riayet edilerek şirket tarafından düzenlenmektedir. Şirket tarafından hazırlanan bir sözleşmenin şekle aykırılığının yine bu tarafça ileri sürülmesi TMK. m. 2/1 kapsamında dürüstlük 
kuralına aykırılık teşkil edecek ve hakkın kötüye kullanılması anlamına gelecektir. Bu sebeple, TKHK m. 32/2 gereği "geçerli bir sözleşme yapmamış olan konut finansmanı kuruluşu, sonradan sözleşmenin geçersizliğini tüketici aleyhine olacak şekilde ileri süremez" kuralının tasarruf finansman şirketleri için de getirilmesi gerekir. Çünkü sözleşmenin yazılı olarak veya yazılı şekil yerine geçecek usulde düzenlenmesi şirketin yükümlülügüüür. Bu yükümlülüğü yerine getirmeyen tasarruf finansmanı şirketine de sözleşmeyi geçersiz kılma hakkı tanınmamalıdır.

\section{TASARRUF FİNANSMAN SÖZLEŞMESINIIN HÜKÜMLERİ}

Tasarruf finansman sözleşmesinin taraflarının, tasarruf finansman şirketi ve müşteri (ticari amaçla yapılan sözleşmeler hariç tüketici) olduğunu önceki açıklamalarımızda ifade etmiştik. Bu başlık altında tarafların borçlarını inceleyerek, sözleşmenin hükümlerini ele almış olacağız.

\section{A. Müşterinin Borçları}

\section{Sözleșme Görüşmeleri Așamasında Şirkete Bilgi Verme Borcu}

Sözleşme kurulmadan önce taraflar sözleşmenin şartları ve içeriği ile ilgili görüşmeler yaparken aynı zamanda birbirleri hakkında da güven tesis etmeye çalışmaktadırlar. Zira, müşterinin şirkete ve sisteme duyacağ 1 güven kadar, şirketin de uzun vadeli bir geri ödeme planı içine girecek olan müşterinin kimliği ve ekonomik durumu hakkında müşteriye güven duyması gerekmektedir. Taraflar arasında tesis edilecek bu güven ilişkisi neticesinde sözleşmenin kurulması söz konusu olacaktır. Bu aşamada taraflar arasında edim yükümlülüklerinden bağımsız davranış yükümlülükleri doğar. Doktrinde, sözleşmeden önce taraflar arasında bu güven ilişkisi ile sözleşme benzeri bir hukuki ilişki doğduğu ve bu aşamada da tarafların birbirlerine karşı duydukları güvenin boşa çıkması neticesinde sorumlu olacakları kabul edilmektedir ${ }^{24}$.

Bir sözleşmenin tarafları, TMK. m. 2/1'e göre dürüstlük kuralı gereği görüşme aşamasında birbirlerine karşı aldatıcı davranışta bulunmamayı, kendileriyle ilgili gerekli bilgileri karşı tarafa vermeyi borçlanmaktadırlar. Taraflar verecekleri bilginin doğruluğundan da bu kapsamda sorumlu olacaklardır. Önceki açıklamalarımızda da ifade ettiğimiz üzere tasarruf finansman sözleşmesinde müşterinin kimliğini belgelemesi geçerlilik şartı olarak öngörülmüş olsa da müşteri kendi ile ilgili verdiği bilgilerin doğruluğundan da dürüstlük kuralı gereği sorumlu olacaktır. Diğer bir ifade ile müşterinin kimliğini belgelemesi zorunluluğu sözleşme için bir geçerlilik şartı olarak öngörülmüş olması tarafların sözleşme öncesi görüşmeler çerçevesinde kurulan güvene dayalı hukuki ilişkinin ihlal edilmesi neticesinde doğan zararlardan sorumlu olmalarına engel değildir ${ }^{25}$. Tasarruf finansman sözleşmesi kurulurken müşterinin verdiği bilgilerin, kimliğinin doğrulanması, şirketin bu doğrulamayı sağlayacak yöntemleri sözleşmede kullanması gerektiği Kanun’un 39/A, f. 2 maddesinde de hüküm altına alınmıştır. Bu sebeplerle şirketi yanıltan, kimliği veya kendi ile ilgili

\footnotetext{
${ }^{24}$ Eren, 1157 vd.; Antalya, 227 vd.; Ulusan, İlhan. Culpa in Contrahendo Üstüne, Prof. Dr. Ümit Doğanay’ın Anısına Armağan 1, İstanbul 1982, s. 285 vd.; Von Thur, 198; Serozan, Rona. "Culpa In Contrahendo", “Akdin Müspet İhlali”" ve "Üçüncü Kişiyi Koruyucu Etkili Sözleşme” Kurumlarının Ortak Temeli: Edim Yükümlülüklerinden Bağımsız Borç İlişkisi, İstanbul Üniversitesi Mukayeseli Hukuk Araştırmalart Dergisi, C. 2, S. 3, 1968, 117,119 vd., https://dergipark.org.tr/tr/pub/iumhad/issue/1282/15108, (E.T. 15.04.2021); Arat, Ayşe. Konut Satışında Üç Köşseli İlişkilerden Doğan Sorumluluk, İstanbul 2018, 258 vd.

${ }^{25}$ Doktrinde bugün hâkim olan görüş, sözleşme görüşmelerinden sorumluluğun doğması için sözleşmenin kurulmuş olmasının ya da kurulmamasının veya bâtıl sayılmasının yahut geçerli olmasının şart olmadığı yönündedir. Bkz. Eren, 1157; Serozan, 117 vd.; Gonzenbach, Rainer. Culpa in contrahendo im schweizerischen Vertragsrecht, Bern $1987,7$.
} 
diğer hususlara dair yanlış, yanıltıcı bilgi veren müşteri TMK. m. 2/1 gereği sözleşme öncesi şirket ile aralarında kurulan güven ilişkisinin ihlal edilmesi sebebiyle şirket aleyhine doğan zararlardan sorumlu olacaktır. Söz konusu zararlara kusurlu davranışı ile sebep olan müşterinin sorumluluğu "culpa in contrahendo" hükümlerine dayanacaktır"26.

\section{Tahsisatı Kabul Etme Borcu}

Tasarruf finansman sözleşmesi kapsamında müşteri, sözleşmedeki şartlar dahilinde tasarruf birikimleri ve kendisine ödenmesi taahhüt edilen finansman tutarının toplamı olan tahsisat ödemesini şirket tarafından kullanıma sunulduğu anda kabul etme borcu altındadır. Ancak müşteri ihtiyacı olan konut, çatılı işyeri veya taşıtı tahsisat zamanı geldiğinde temin edememişse, 6361 sayılı Kanun m. 39/A, f. 4'e göre tahsisatın ertelenmesini isteme hakkına sahiptir. Erteleme halinde müşterinin sözleşmeden doğan hak ve yükümlülükleri saklı tutulmuştur.

Müşterinin alacağı olan tahsisat ödemesini kabul etmemesi Borçlar Hukuku anlamında alacaklı temerrüdünün sonuçlarının doğması gerektiği düşüncesini akla getirebilir. Öncelikle şirket, tahsisat ödemesini doğrudan müşteriye yapmamaktadır. 6361 sayılı Kanun'un 3/1-k hükmüne göre tahsisat ödemesi “...müşterinin, mirasçısının veya vekilinin konut, çatılı iş yeri veya taşıt edinmesi amacıyla satıcı konumundaki üçüncü kişilere hesaben” gerçekleştirilir. Dolayısıyla tahsisat ödemesinin yapılabilmesinin ön şartı müşterinin finansman ihtiyacı duyduğu konutu, çatılı işyerini veya taşıtı bulmuş, satıcı ile devir için mutabakata varmış olmasıdır. Diğer yandan, müşterinin tahsisatın ödenme zamanı geldiğinde ödemeyi kabul etmemesi şirket açısından bir dezavantaj yaratmayacaktır. Zira, şirket sadece finansman teminini borçlanmamakta, müşteri tarafından yatırılan tasarruf birikimlerinin yönetilmesini de borçlanmaktadır. Müşteriye yapılacak ödeme tasarruf fon havuzunda şirket tarafından yönetilmeye, bunun doğal sonucu olarak da getiri elde edilmeye devam edilecektir. Bu sebeple, müşterinin tahsisat ödemesini kabul etmemesi veya ödemenin ertelenmesini istemesi sözleşme hükümleri gereği Borçlar Hukuku anlamında alacaklı temerrüdü teşkil etmeyecektir.

\section{Finansmanı Geri Ödeme Borcu}

Müşterinin tasarruf finansman sözleşmesinden doğan en temel borcu sözleşme konusu finansmanı geri ödemesidir. Müşterinin geri ödeme borcu sözleşmenin kurulmasına bağlıdır. Sözleşme taraflar arasında kurulduktan sonra müşteri sözleşmede kararlaştırılmış olan ödeme takvimine göre geri ödeme borcunu ifa etmeye başlamaktadır. Bu sebeple müşterinin borcu dönemli (devri) edimli borçtur ${ }^{27}$.

Müşteri, geri ödemede gecikirse veya hiç ödeme yapmazsa temerrüde düşmüş sayılacaktır. Ancak, Kanun'da ve Yönetmelikte temerrüde dair detaylı bir düzenleme getirilmemiştir. 6361 sayılı Kanun m. 39/A, f. 5 ve Yönetmelik'in 16/4 hükümlerine göre tarafların temerrüdüne dair

\footnotetext{
${ }^{26}$ Sözleşme görüşmelerine başlayanlar arasında TMK. m. 2 gereği dürüstlük kuralı çerçevesinde doğan güven ilişkisi içinde taraflar birbirlerinin şahıs ve malvarlığı değerleri üzerinde etkili doğurabilecek bir duruma gelirler. $\mathrm{Bu}$ süre zarfinda birbirlerine doğru bilgi verme, bazı hususlara dair açıklayıcı bilgilendirmelerde bulunma ve karşı akidi muhtemel zararlardan koruyacak tedbirler alma yükümlülükleri doğar ki, bu yükümlülüklere kusurlu olarak aykırı davranan sözleşme tarafları karşı tarafa verdikleri zararı tazminle mükellef olurlar. Eren, 1157; Gonzenbach, 7, 71, 92 vd.; Arat, 259.

${ }^{27}$ Von Thur, 50; Eren, 108. Oğuzman, K./ Öz, T.. Borçlar Hukuku Genel Hükümler, C.1, Gözden Geçirilmiş 12. B., İstanbul 2014, 13; Altık Ormanc1, 17 vd.; Antalya, 105.
} 
hükümlerin sözleşmenin asgari unsurları olarak sözleşme kapsamında düzenlenmesi gerekmektedir. $\mathrm{Bu}$ sebeple temerrüdün şartları ve uygulanacak hükümler taraflarca sözleşmede kararlaştırılacaktır ${ }^{28}$.

6361 sayılı Kanun ve Yönetmelik'in temerrüde ilişkin hükümleri sözleşmede kararlaştırılması gereken zorunlu asgari unsurlar içinde kabul etmesi sebebiyle müşterinin geri ödeme borcunun ifasında temerrüde düşmesi halinde öncelikle uyuşmazlığın sözleşme hükümlerine göre çözülmesi gerekecektir. Bu hükümlerin tespitinde de emredici kurallara aykırı olan ve şirket ile müşteri arasında tüketici ilişkisinin mevcut olduğu hallerde de haksız şart niteliğinde olan hükümler kesin hükümsüz sayılacaktır. Sözleşme hükümleri mevcut uyuşmazlığı çözmeye yeterli olmazsa tasarruf finansman sözleşmesinin düzenlendiği Kanun ve ilgili Yönetmelik hükümlerine, burada da uyuşmazlığı çözmeye yetecek hüküm bulunamazsa müşteri ve şirket arasındaki ilişkiye göre TKHK (tüketici ilişkisi mevcut ise öncelikle TKHK hükümleri uygulanacaktır), TBK veya TTK'nın genel veya özel hükümlerine doğrudan veya kıyasen başvurulması gerekecektir.

Sonuç olarak, 6361 sayılı Kanun ile bir tip sözleşme niteliği kazanan tasarruf finansman sözleşmesi için hukuki alt yapının oluşturulduğu bu dönemde şirketler tarafından müşterinin haksız uygulamalara maruz kalmasını önlemek adına Yönetmelik'e temerrüde dair TKHK'daki konut finansmanı sözleşmesinde öngörülen hükümlere benzer detaylı emredici veya en azından tamamlayıcı kuralların konulması gerektiği kanaatindeyiz.

\section{Teminat Gösterme Borcu}

Tasarruf finansman şirketi ve müşteri arasında tasarruf finansman sözleşmesi ile kurulan uzun süreli ve yüksek meblağlı hukuki ilişki, şirketleri alacaklarını güvence altına alma zorunluluğunu doğurmaktadır. $\mathrm{Bu}$ amaçla bazı şirketler düzenleme öncesi dönemde tasarruf dönemi veya finansman dönemi gibi ayrımlara gitmeden ipotek, rehin, kefil veya senet gibi çeşitli güvencelere başvurmuşlardır.

Yönetmelik'in 16/4-ç hükmüne göre "finansman tarihi itibariyle finansman dönemi için talep edilmesi öngörülen teminatlar" sözleşmenin asgari unsurları arasındadır ve sözleşmede önceden taraflarca kararlaştırılması gerekmektedir. Ayrıca Yönetmelik'in 17/7 maddesinde tasarruf dönemine ilişkin müşteriden herhangi bir teminat alınamayacağı, müşteriyi organizasyon ücreti dışında bir ödeme yükümlülüğü altına sokacak hukuki işlem yapılamayacağı açıkça düzenlenmiştir. Bu hükümlere göre şirket, müşteriden sadece finansman dönemine ait olmak üzere

\footnotetext{
${ }^{28}$ Mevcut düzenleme öncesi yapılan sözleşmelerde müşterinin taksitlerin ödemesinde gecikme yaşanması halinde geciken ay sayısı kadar tahsisat ödemesinin erteleneceği, geciktirdiği aylara ilişkin gecikme bedeli yansıtılacağı ve tahsisat ödemesi yapıldıktan sonra üst üste iki ay taksitlerin ödenmemesi halinde de geriye kalan vadelerin de muaccel olacağ1 öngörülmekteydi. Eski sözleşmelerde temerrüde için uygulanan bu hükümler TKHK m. 34'te konut finansmanı sözleşmesi için öngörülen temerrüt hükümleri ile benzerlik göstermektedir. TKHK m. 34'e göre temerrüt hükümlerinin uygulanabilmesi için tüketicinin birbirini izleyen en az iki taksiti ödemede temerrüde düşmesi ve kuruluşun bütün edimlerini ifa etmiş olması ve tüketiciye en az otuz gün süre vererek muacceliyet uyarısında bulunması gerekmektedir. Bu şartlar gerçekleşmeden kuruluş, kalan borçların tamamını muaccel sayamayacaktır. Bu sebeple sözleşme hükümlerinin haksız şart teşkil etmemesi için TKHK kapsamında mevcut olan hükümlerin kıyasen temerrüt hükümleri için de uygulanması, bu hükümlerin yetersiz kalması halinde de genel hükümlere başvurulması gerekmektedir.
} 
yani finansman tarihi itibariyle, tahsisat ödemesinin yapılmasını takiben kalan borçlar için teminat talep edebilecektir. Bunun dışında hiçbir surette tasarruf birikimi yapıldığı dönemler için müşteriden kefil, senet, rehin, ipotek gibi bir teminat istenemeyecektir. Söz konusu düzenlemelerin Kanun'un 39/A maddesinin 3. ve 4. fikralarında hüküm altına alınmış olan müşterinin cayma veya fesih haklarını da desteklediği kanaatindeyiz. Aksi halde müşteri yükümlü kılındığı teminatlar sebebiyle sözleşmeyi sona erdiremeyecek, devam etmek istemediği bir hukuki ilişki içinde bu ilişkiyi sürdürmeye mahkûm edilecektir. Bu sebeple müşteri, şartları dahilinde sözleşmenin akdedilmesinden itibaren hiçbir sebep göstermeden on dört gün içinde cayma hakkını, tasarruf dönemi bitene kadar da sözleşmeyi feshedebilecektir.

\section{Organizasyon Ücreti Ödeme Borcu}

Tasarruf finansman sözleşmesinin Kanun'da yapılan tanımına göre tasarruf finansman şirketi müşteriden organizasyon ücreti alma hakkına sahiptir ${ }^{29} .6361$ sayılı Kanun'un 3/1-j hükmüne göre organizasyon ücreti, “müşterilerin tasarruf finansman sözleşmesi kapsamında tasarruf finansman faaliyeti ve tasarruf fon havuzunun yönetimi karşılığında ödeyecekleri tutar"dır. Organizasyon ücreti, şirketin genel faaliyet ilkeleri dokümanı kapsamında faaliyete başlamadan önce Kurum'un onayını alması gereken asgari unsurlardan biridir. Bu sebeple şirketin sözleşmede Kurum'un onay verdiği esaslar çerçevesinde ücret talep edebilmesi gerekmektedir.

Kanun'un 39/A, f. 5 ve Yönetmelik'in 16/4-f hükümlerine göre organizasyon ücreti sözleşmenin asgari unsurları arasında yer almaktadır. Yönetmelik m. 29'da şirketin, her sözleşme için organizasyon ücretini ve sözleşmeye dahil masrafları içeren toplam maliyet hesaplaması yapmak suretiyle bir tarife oluşturması, maliyetler hakkında müşteriyi bilgilendirmesi gerektiği öngörülmüştür. Yönetmelik' in 17/7 hükmüne göre de şirket müşteriyi organizasyon ücreti dişında başka herhangi bir ödeme yükümlülüğü altına sokamaz. Tüm bu hükümler sözleşmenin tanımı ile birlikte değerlendirildiğinde müşterinin ödemekle yükümlü olduğu, sözleşmeden doğan asli edim yükümlülükleri, finansmanı geri ödeme borcu ve organizasyon ücreti ödeme borcudur ${ }^{30}$.

Organizasyon ücretinin ne zaman ve nasıl ödeneceğine dair mevcut düzenlemelerde bir açıklık yoktur. Müşteri sözleşmenin kurulmasıyla beraber bu borcu ödeme yükümlülüğü altına girmektedir, ancak ücreti defaten mi yoksa taksitler halinde, finansman geri ödemesi ile birlikte mi ödeyeceği hususu belirsizdir. Yönetmelik' in 17/3. maddesinde "grup müşterileri için çekilişli gruplarda, grubun toplam tasarruf ay sayısının asgari yüzde kırkı kadar sözleşme ilişkisi kurulmuş müşteri bulunması zorunluluğu olduğu ve bu orana ulaşamamış gruplarda tasarruf döneminin başlatılamayacă̆l, organizasyon ücretinin de alınamayacă̆ ”" düzenlenmiştir. Bu hükümden çıkaracağımız sonuç müşterinin organizasyon ücretini, tasarruf döneminin başlamasıyla beraber

\footnotetext{
29 Eski uygulamalarda bu ücret şirket tarafindan yürütülen faaliyetlere karşılık, "çalışma ücreti” adı altında alınmaktaydı. Çalışma ücretini peşin ödenmeyi kabul eden müşterilere çeşitli kampanyalar altında müşterinin finans döneminin daha yakın takvimde çıkma ihtimali olan gruplara kaydedilmesi imkânı sunuluyordu. Mevcut düzenlemelerle hem organizasyon ücretine hem de buna dair sözleşmeye konulacak hükümlerin dayandığı esasların önceden BDDK'nın denetiminden geçecek olmasının müşterinin lehine olduğu kanaatindeyiz.

${ }^{30}$ Asli edim yükümlülükleri, sözleşmenin türünü, tipini, nitelik ve özelliklerini belirleyen, borçlunun yerine getirmek zorunda olduğu asıl borcunu ifade etmektedir. Borç ilişkisinin birinci derecedeki içeriğini oluşturan, yan edim yükümlülüklerinden bağımsız olarak doğrudan dava edilebilen bu yükümlülükler, alacaklının alacak hakkının da nedenidir. Tasarruf finansman sözleşmesinin de Kanun'da yapılan tanımında da şirketin organizasyon ücreti alacak hakkının varlığından söz edilmektedir. Bu durumda müşterinin asıl borçlarından biri de organizasyon ücretinin ödenmesi olacaktır. (Asli edim yükümlülüğü hakkında bkz. Eren, 31 vd.)
} 
ödeme yükümlülügü̈ altında olduğudur. Tasarruf dönemi başlamamış olan müşterilerden organizasyon ücretinin ifası istenemeyecektir. Organizasyon ücretinin defaten mi yoksa taksitle mi ödenmesi gerektiği hususunu da sözleşme serbestisi ilkesi gereği Kurum'un onayladığı genel faaliyet ilkeleri dokümanına uygun olmak kaydıyla taraflar sözleşmede kararlaştıracaklardır.

\section{Sigorta Borcu}

Günümüzde yürütülmekte olan kredi veya finansman teminine dair finansal faaliyetler kapsamında (TKHK'da düzenlenen tüketici kredi sözleşmelerinde, konut finansmanı sözleşmesinde, bunun dişında bankalardan temin edilen bireysel kredilerde, 6361 sayılı Kanun'a göre finansman sözleşmelerinde vb.) müşterilere/ tüketicilere krediye veya finansmana bağl1 sigorta yaptırma yükümlülüğü getirildiği görülmektedir. 6361 sayılı Kanun'da yapılan düzenlemelerle tasarruf finansman sözleşmesi kapsamında da müşteriler, şirketler tarafindan kullandırılacak finansmana ilişkin sigorta yaptırma zorunluluğu altındadır. Zira; şirketler, müşteriye kullandıracakları finansmanı güvence altına alma ihtiyacı duymaktadırlar. Bu sebeple Yönetmelik'in 16/4-i maddesinde sözleşmenin asgari unsurları içinde müşteriye kullandırılacak sigorta politikasına ve buna dair esaslara ilişkin hükümlerinde olması gerektiği düzenlenmiştir. Mevcut düzenlemeler sigorta borcunun kapsamına ve uygulanacak esaslara dair detaylı bir hüküm öngörmemektedir. Sadece sözleşmenin asgari unsurları içinde sigorta politikası ve sigortaya ilişkin ilgili hükümlerin hükümlere sözleşme metninde yer verilmesi gerektiği düzenlenmiştir. Buna göre sözleşme metninde "kullandırlacak finansmana ilişkin sigorta politikasına, sigortalanacak tutara, müşteri tarafindan ödenecek sigorta primine ve müşterinin mevcut sigorta poliçelerinin kabul şartlarına" dair hükümler yer almalı ve taraflar bu hususta karş1lıklı, birbirine uygun irade uyuşması ile mutabakata varmalıdır.

Müşteriye/tüketiciye kredi veya finansmana bağlı olarak sigorta yükümlülüğü öngören, TKHK. m. 38 ve 28.05.2015 tarihli “Konut Finansmanı Sözleşmeleri Yönetmeliği” gibi ilgili mevzuatlar gereği sigorta yükümlüsünün yazılı izni veya kalıcı veri saklayıcıları aracılığıyla açık talebi olmaksızın sigorta yaptırabilmesi mümkün değildir. Bu sebeple 6361 sayılı Kanun’da yapılan düzenleme öncesi faizsiz finansman sözleşmelerinde müşteriden sigorta yaptırılmasına dair yazılı izin alınmaktaydı. Müşteri, finansman konusuna göre gerekli olan zorunlu deprem sigortası (DASK), konut sigortası, trafik sigortas1, kasko sigortası gibi gerekli olan bütün sigortaları yaptırmayı, yeniletmeyi ve yapılan sigortalara da şirketin "dain-i mürtehin"31 olarak poliçelere şerh ettireceğini, bu borcunu yerine getirmediği takdirde ise masrafları müşterinin tasarruf birikimlerinden karşılanmak kaydıyla şirket tarafından zorunlu ve isteğe bağlı tüm sigortaların yapılmasını taahhüt etmekteydi. Düzenlemeler sonrası yeni sistemde de şirket, sözleşmeye koyacağı sigorta politikası ile ilgili hükümlerde tüketici ilişkisi kurulan hallerde TKHK ve ilgili yönetmelik hükümlerini kıyasen uygulamak suretiyle, diğer hallerde de 5684 sayılı Sigortacılık Kanunu başta olmak üzere ilgili yönetmelik hükümlerine uygun sözleşme içeriğini düzenlemelidir.

\footnotetext{
${ }^{31}$ Kredinin geri ödenmeme riskini ortadan kaldırmak amacıyla yaptıılan sigortalarda, riskin gerçekleşmesi üzerine ödenecek olan tazminat tutarından birinci derecede alacaklı olan gerçek veya tüzel kişiyi ifade etmektedir.
} 


\section{B. Tasarruf Finansman Şirketinin Borçları}

\section{Sözleşme Görüşmeleri Aşamasında Müşteriye Bilgi Verme Borcu}

6361 sayılı Kanun'un 39/A, f. 5 ve Yönetmelik'in 16/5, 17/2, 29/1 maddelerinde tasarruf finansman şirketinin müşteriyi bilgilendirme yükümlülüğünden bahsedilmektedir. Bu kapsamda şirket, müşterilerini tasarruf finansman sisteminin işleyişi ${ }^{32}$, tasarruf finansman sözleşmelerinde yer alan hükümler (tasarruf finansman sözleşmelerindeki asgari olarak tutarlara, vadeye, organizasyon ücretine, gelir, maliyet ve masraflara, konut, çatılı iş yeri veya taşı edinimine yönelik tasarruf etme ve finansman kullandırma dönem ve koşullarına, iade süresi ve şartlarına, temerrüde, mirasçılara intikaline, üçüncü taraflara devrine, tarafların hak ve yükümlülüklerine vb.), cayma ve fesih hakları konusunda etkin bir şekilde bilgilendirmek ile yükümlüdür.

Şirketin müşteriyi bilgilendirme yükümlülüğü sözleşme görüşmeleri, yani hazırlık aşamasında doğan bir borçtur ${ }^{33}$. Taraflar, sözleşmenin şartları ve içeriği konusunda görüşmeler yaparken, müşterinin geri ödeme yapıp yapamayacağını, sistemin güvenilirliğini değerlendirmekte ve sözleşme bu güven üzerine akdedilmektedir. Taraflar sözleşme görüşmeleri sırasında birbirlerini sözleşmenin asli ve önemli noktaları hakkında aydınlatmak zorundadır. Bu noktada bilgilendirme yükümlülüğü sözleşmenin kurulmasından önce doğduğu için TMK. m. 2'ye, dürüstlük kuralına dayanmaktadır. Baka bir ifade ile bilgilendirme yükümlülüğü, dürüstlük kuralından doğan yan yükümlülüktür. Bu yükümlülüğün ihlal edilmesi ise "culpa in contrahendo" hali oluşturacaktır ${ }^{34}$.

Yönetmelik'in 16/5 maddesine göre bilgilendirme yükümlülüğü ifa edilirken "TKHK ve bu kanuna ilişkin alt düzenlemelerde yer verilen hükümlere" de riayet edilmesi gerekecektir. TKHK. m. 4/1'e göre yazılı olarak düzenlenecek bilgilendirmelerin "en az on iki punto büyüklüğünde, anlaşılabilir bir dilde, açık, sade ve okunabilir bir şekilde düzenlenmesi” ve bunların bir nüshasının kâğıt üzerinde veya kalıcı veri saklayıcısı ile tüketiciye verilmesi gerekmektedir. $\mathrm{Bu}$ düzenleme sadece yazılı sözleşmeler için getirilmiştir. Ancak, mesafeli sözleşme görüşmelerinde veya tasarruf finansman sözleşmesinin yazılı şekil yerine geçecek yöntemlerle yapılması halinde bilgilendirmenin nasıl yapılması gerektiğine dair bir netlik yoktur. Sadece, "Finansal Kiralama, Faktoring, Finansman ve Tasarruf Finansman Şirketlerince Kullanılacak Uzaktan Kimlik Tespiti Yöntemlerine ve Elektronik Ortamda Sözleşme İlişkisinin Kurulmasına İlişkin Yönetmelik Taslağı”nın 8/5. maddesinde görüşme yapılan kişinin sözleşme öncesi görüşmelerde uzaktan kimlik tespitinin yapıldığ1 görüntülü görüşmelerde şirket tarafından verilecek hizmetler hakkında bilgilendirilmesi gerektiği ve bu kişinin şirket müşterisi olacağını kabul ettiğini sözlü olarak onaylaması halinde sürecin tamamlanmış olacağı ifade edilmiştir ${ }^{35}$. Ne

\footnotetext{
${ }^{32}$ Yükümlülüğün kapsamına verilen hizmetle ilgili müşterileri bilgilendirmek de dahildir. Yönetmelik'in 17/4 hükmündeki düzenlemeye göre şirket, hizmetle ilgili sorulan sorulara cevap verecek bir sistem kurmakla yükümlüdür. Böylece müşterilerin veya sisteme dahil olmak isteyen bireylerin her konuda bilgilendirilmesi amaçlanmaktadır.

${ }^{33}$ Her ne kadar bilgilendirme yükümlülüğü sözleşme öncesi aşama ile başlıyor olsa da bununla sinırlı değildir ve sözleşme kurulduktan sonra da devam eder. Bkz. Bellican, Cüneyt. 6502 Sayılı Tüketicinin Korunması Hakkında Kanun Kapsamında Bilgilendirme Yükümlülüğünün Değerlendirilmesi, İstanbul Kültür Üniversitesi Hukuk Fakültesi Dergisi, C. 16, S. 2- 1, Temmuz- Ağustos 2017, 305, https://www.jurix.com.tr/article/9664, (E.T. 17.04.2021).

${ }^{34}$ Eren, 37 vd.; Antalya, 255.

${ }^{35} \mathrm{Bu}$ hüküm göstermektedir ki, müşteri olmak isteyen bir gerçek veya tüzel kişi müşteri olacağını sözlü olarak onaylamadığı takdirde sözleşme kapsamına dair bilgi sahibi olmamakta, hangi hükümlerle karşılaşacağını bilmemektedir. Müşteri temsilcinin hizmetle ilgili verdiği bilgiler ile yetinmek durumundadır.
} 
söz konusu hükümde ne de Yönetmelik taslağının diğer hükümlerinde bilgilendirme yükümlülügünün nasıl yapılacağına dair tatmin edici bir düzenleme bulunmamaktadır. $\mathrm{Bu}$ kapsamda muhakkak ki taslağa eklenecek detaylı düzenlemeler ile müşteriye bilgilendirme yükümlülüğü kapsamında sözleşme hükümlerini inceleme ve yeterince düşünme imkanını tanımak gerekmektedir. Diğer yandan, TKHK. m. 4/4'te tüketiciden talep edilecek bilgilerin uzaktan iletişim araciyla kurulan sözleşmelerde bu sisteme uygun olarak verilmesi gerektiği düzenlenmiştir. Bunun dışında TKHK. m. 49 vd.'da "finansal hizmetlere ilişkin mesafeli sözleşmelerde" sözleşmenin kurulmasından önce tüketicinin cayma hakkı ve sözleşme ile gireceği yükümlülüklere dair ayrıntılı bilgilendirmenin açık, anlaşılır bir şekilde kullanılan uzaktan iletişim aracına uygun şekilde yapılması zorunluluğu getirilmiştir. 31.01.2015 tarihli 29253 Sayılı "Finansal Hizmetlere İlişkin Mesafeli Sözleşmeler Yönetmeliği”"nin 5 vd. maddelerinde de ön bilgilendirme yükümlülüğüne ve yöntemine dair detaylı düzenlemeler mevcuttur. Sonuç olarak kanaatimizce en azından yürürlüğe girdiği andan itibaren özel hüküm niteliği taşıyacak olan Yönetmelik taslağında da bu düzenlemelerle uyumlu, içerik olarak detaylı ve tatmin edici hükümlere yer verilmesi gerekmektedir.

Bilgilendirme yükümlülüğüne dair benzer bir düzenlemede konut finansmanı sözleşmesi için TKHK. m. 33'te öngörülmüştür. Bu hükme göre, konut finansman kuruluşları sözleşmenin koşullarını içeren sözleşme öncesi bilgi formunu, sözleşmenin kurulmasından "makul bir süre önce" tüketiciye vermek zorundadır. Söz konusu hükümlerden de anlaşılacağı üzere 6361 sayılı Kanun ve Yönetmelik'te bilgilendirme yükümlülügüne dair getirilen düzenlemeler TKHK ile uyuşmaktadır. Ancak Yönetmelik'in 16/5 maddesinde şirketin, sözleşmenin kurulmasından en az bir gün önce sözleşmenin ön bilgilendirme formunu müşteriye iletilmekle yükümlüdür ${ }^{36}$. Bilgilendirme formunun en az bir günlük süreden ziyade konut finansmanı sözleşmesinde olduğu gibi makul bir süre olarak öngörülmesi müşterinin lehine sonuç doğuracağı kanaatindeyiz. Zira, bu süre içinde müşterilere (tüketiciye) son kez düşünme ve araştırma imkânı tanınmaktadır. Müşteri kendisini uzun süre borçlandıracak bir sözleşme ilişkisi için önceden öğreneceği şartları detaylı düşünecek ve kararlarını bilinçli olarak verebileceği makul bir süreye sahip olmalıdır. Şirketler benimseyecekleri işleyiş politikaları ile bilgilendirme formunu sözleşmenin yapılmasından bir gün önce göndererek hem bu yükümlülügünü ifa etmiş olurlar hem de müşteriyi acele ettirerek sözleşmeden vazgeçme ihtimalini ortadan kaldırmaya çalışabilirler. Bu sebeple tasarruf finansman sözleşmesi için Yönetmelik’te öngörülen bilgilendirme süresinin, şirketlerin

\footnotetext{
36 Yönetmelik taslağı ilan edildiğinde 16/5 hükmünde şirketin bilgilendirme formunu müşteriye gönderme "zorunluluğu" altında olduğu ifade edilmekteydi. Bu ifade ilk etapta bilgilendirmenin tasarruf finansman sözleşmesinin yapılması için bir geçerlilik şartı gibi değerlendirilmesine yol açabilecekti. Kural koyucu "zorunluluk" ifadesini kullanmış olsa dahi bilgilendirme yükümlülüğünün veya daha genel bir tabirle bilgilendirme şartının hukuk düzenimiz içinde ele alınışı incelendiğinde ve hukuk kuralının yorumlanması neticesinde yine bu hükmün bir yükümlülük olarak anlaşılması gerekecekti. Öyle ki, öncelikle bilgilendirme şartı hukukumuzda birçok sözleşme ilişkisi içinde yükümlülük olarak düzenlenmiştir (avukatın bilgilendirme yükümlülüğü, tüketicinin bilgilendirilme yükümlülüğü, bankaların bilgilendirme yükümlülüğü, doktorun bilgilendirme yükümlülüğü gibi). Bu durumda Yönetmelik taslağındaki hükmün lafzî yorumu neticesinde zorunluluk olarak tespit edilebilecek bu düzenleme, hukukumuzdaki diğer düzenlemelerle mukayese edildiğinde bir ilk teşkil edecekti. Diğer taraftan, kural koyucunun bu kuralı koymakta ki amacının ne olacağı düşünüldüğünde burada bir geçerlilik şartından ziyade, müşteriyi korumaya yönelik şirket aleyhine bir yükümlülük tesis edilmeye çalışıldığı sonucuna varılacaktı. Bu sebeple metindeki yorum sorunu teşkil eden "zorunluluk" ibaresinin yürürlüğe giren Yönetmelik metninde düzeltilerek, "yükümlülük" olarak hüküm altına alınması yerinde olmuştur.
} 
müşteri aleyhine sonuç doğuracak uygulamalarının da önüne geçmek adına, müşterinin lehine olacak şekilde "makul bir süre" ibaresi ile değiştirilmesi gerektiği kanaatindeyiz.

\section{Birikmiş Tasarruf Tutarını Yönetme Borcu}

Tasarruf finansman sözleşmesinin Kanun'da yapılan tanımına göre şirketin asli edim yükümlülüklerinden biri müşterinin birikmiş tasarruf tutarını yönetme borcudur. Müşteri, şirketle sözleşmeyi akdettiği andan itibaren (istisnalar hariç ${ }^{37}$ ) tasarruf ödemesi yapmaya başlamaktadır. Yapılan ödemeler tasarruf fon havuzunda toplanmakta ve şirket müşterinin yaptığı ödemelerle oluşan bu birikimi faizsiz yatırım araçları kullanılmak suretiyle yönetmek zorundadır.

Şirket, tasarruf birikimlerinin yönetilmesi neticesinde getiri elde edecektir. Sözleşmede müşteriye yatırımlar neticesinde getiri saplanması kararlaştırılmışsa şirket elde ettiği getiriyi müşterinin tasarruf birikimlerine ekleyecektir. Ancak müşteriye getiri sağlanması kararlaştırılmamışsa söz konusu getiriler tasarruf fonu havuzunun içine ihtiyat fonu ${ }^{38}$ olarak ayrilır.

\section{Tahsisatı Ödeme Borcu}

Kanun'da yapılan tanıma göre tahsisat ödemesi, şirket tarafından sözleşme uyarınca kararlaştırılan şartların gerçekleşmesi halinde müşterinin, mirasçılarının veya vekilinin konut, çatılı iş yeri veya taşı ihtiyacına karşılık satıcı konumundaki üçüncü kişinin hebasına yapılan tasarruf birikimlerinden ve taahhüt edilen finansman tutarından oluşan toplam ödemedir. Ödemenin kapsamı, müşterinin birikmiş tasarruf tutarı toplamından ve şirketin müşteriye kullandırmayı vaat ettiği finansman tutarından oluşmaktadır. Kanun'un 39/A, f. 1 maddesinde yapılan tasarruf finansman sözleşmesi tanımına göre şirketin diğer asli edim yükümlülükleri de müşterinin birikmiş tasarrufunun geri ödenmesi ve şirketin taahhüt ettiği finansmanı kullandırmasıdır. Bu sebeple tanımda zikredilen her iki yükümlülüğü de kapsamında barındıran tahsisat ödemesi yapma borcu şirketin asıl borçlarından bir diğeridir.

Şirketin tahsisat ödemelerini yapabilmesine dair Yönetmelik'in 21/2 ve 21/4 hükmü ile bazı sınırlamalar getirilmiştir. Buna göre, bireysel ve çekilişli grup sözleşmeleri için müşterilerin belirli bir tasarruf tutarına ulaşmaları zorunlu hale getirilmiş, bu tasarruf tutarının fon havuzunda toplanmadan tahsisat ödemesinin yapılmayacağı hüküm altına alınmıştır. Bu kapsamda; sözleşme süresinin beşte ikisine ulaşılan ve sözleşme tutarının yüzde kırkı kadar tasarruf yapan bireysel müşteriler ile çekilişli gruba girdiği tarihten itibaren üç ay geçmiş ve üç tasarruf ödemesi yapmış çekilişli müşterilere tahsisat ödemesi yapılacaktır. Çekilişte henüz adı çıkmamış olmakla beraber sözleşme gereği dahil olduğu gruba göre ödeme yapılacak olan müşterilerin de "ödeme yapılacak tarih itibariyle grubun sözleşme tutarları toplamının yüzde kırkı kadar bir tutarın şirketin tasarruf

\footnotetext{
${ }^{37}$ Yönetmelik' in 17/3 hükmünde grup müşterilerinin çekilişli gruplarda, grubun toplam tasarruf ay sayısının asgari yüzde kırkı oranında sözleşme ilişkisi kurulmuş müşteri bulunması zorunluluğunu sağlayamaması halinde bu gruptaki müşterilerden tasarruf ödemesi alınmayacağını öngörmüştür.

38 Yönetmelik m. 30’a göre “Şirketler, müşteri giriş veya çıkışları dolayısıyla karşı karşıya kalabilecekleri öngörülmeyen yükümlülüklerini karşılamak üzere tasarruf fon havuzu toplamının asgari yüzde üçünü, tasarruf fon havuzunun içinde ihtiyat fonu olarak tutmakla yükümlüdür. Kurul, asgari ihtiyat fonu oranını yüzde bire kadar azaltmaya veya iki katına kadar arttırmaya yetkilidir. İhtiyat fonunun tutulabileceği yatırım araçları, yalnızca katılım hesaplarından veya en fazla iki gün valörlü olarak nakde dönüştürülebilir yatırım araçlarından oluşabilir."
} 
fon havuzu hesabında toplanması ve grubun toplam süresinin en az beşte ikisinin tamamlanmış olmasi" zorunludur.

Şirket tahsisat ödemelerini müşteriyle yaptığı sözleşme hükümlerine göre bireysel müşteri ve grup müşterileri için öngörülen esaslar çerçevesinde tahsisat tarihi, ön koşulları ve tahsisat sırasına göre yapacaktır. Bu esaslar aynı zamanda genel faaliyet ilkeleri dokümanı kapsamında Kurum'un onayından geçmesi gereken hususlardır. Şirketin tahsisat ödeme tarihi gelen müşteriye ödemeyi yapabilmesi için müşterinin ihtiyacı olan varlığı satın almak üzere bir üçüncü kişiyle anlaşmaya varmış olması gerekmektedir. Çünkü şirket, tahsisat ödemesini müşteriye (mirasçısına veya vekiline) değil, doğrudan satıcı konumundaki üçüncü kişiye yapmaktadır.

\section{SÖZLEŞMENIN SONA ERMESI}

\section{A. Genel Sona Erme Sebepleri}

Her borcun en tabii sona erme sebebi borcun ifa edilmesidir. İfa, borçlanılan edimin konu, zaman ve yer bakımından doğru ve tam bir şekilde yerine getirilmesidir. Borçlu tarafından gereği gibi yapılan ifa ile borçlu borçtan kurtulur ${ }^{39}$.

Kural olarak ifa ile borç ilişkisi değil, borç ilişkisinin içindeki münferit borç sona ermektedir. Özellikle sürekli borç ilişkilerinde her bir vadeye ait ifa ile borç ilişkisinin ifa edilen kısmı sona ermektedir. Borç ilişkisinin sona ermesi son vadeye bağlı borcun ifası ile olacaktır. Tasarruf finansman sözleşmesi kapsamında müşterinin geri ödeme borcu da dönemli edimdir. Bu sebeple tasarruf finansman sözleşmesi kapsamında müşterinin kullanacağ finansmanın geri ödemelerinin uzun bir dönemine yayılmış olduğu borç ilişkisinde sözleşmenin sona ermesi neticesini doğuracak ifa, müşterinin son taksitini ödemek amacıyla gerçekleştirdiği ifadır.

İfa dişında borç ilişkisini sona erdirebilecek başka sebepler de mevcuttur. Kural olarak sözleşmenin taraflarından birinin ölümü, fiil ehliyetini kaybetmesi veya iflası ve ödemeden aczi sözleşmeyi sona erdirmez. Ancak taraflar anlaşarak bu sebepleri sona erme sebebi olarak belirleyebilirler. Sözleşmenin sona ermesine dair Borçlar Hukuku'ndaki temel prensipler tasarruf finansman sözleşmesi için de geçerlidir. Anonim şirket şeklinde kurulacak olan (6361 sayılı Kanun m. 5/1-a) tasarruf finansman şirketi, tahsisat ödemesi borcunu ifa etmeden iflas ederse veya tüzel kişiliği sona ererse sözleşme kendiliğinden sona erer.

Müşterinin ölmesi veya fiil ehliyetini kaybetmesi sözleşmenin geçerliliğini etkilemez. Ancak burada üzerinde durulması gereken finansman ödemesinin yapılmasından önce mi sonra mı ölüm veya fiil ehliyeti kaybının gerçekleştiğidir. Bu iki ihtimalin ayrı ayrı değerlendirilmesi gerekir. Gerek finansman ödemesi yapılmadan önce gerekse ödeme yapıldıktan sonra müşterinin fiil ehliyetini kaybetmesi halinde, onun adına ve hesabına yasal temsilcisi ödemeleri yapmaya devam edecektir. Diğer yandan, ödeme yapılmadan müşterinin ölmesi halinde sözleşme kendiliğinden sona ermez. Mirasçılar kanuni halefiyet gereği sözleşmenin tarafı haline gelir, ancak mirasçının sözleşmeyi devam ettirmeme hakkı vardır. Dilerse Kanun'un tanıdığı fesih hakkını kullanmak suretiyle sözleşme ilişkisini sona erdirebilir. Burada finansman ödemesi yapılmadan müşterinin ölmesi halinde şirketin ödemeden kaçınıp kaçınmayacağının da ele alınması gerekir. Şirket, sözleşme yapılırken müşteriden alacağını güvence altına almaya yönelik birçok teminat

Eren, $932 \mathrm{vd}$. 
almaktadır. Ölüm veya fiil ehliyetinin kaybı borçların ödenememesi ihtimalini arttırsa da şirket aldığı teminatlarla bu riski de bertaraf etmiş olmaktadır. Zira, mirasçılar kanuni halefiyet gereği murisin borçlarından TMK. m. 641/1 hükmü gereği müteselsilen sorumludur. İkinci ihtimal olarak, finansman ödemesi yapıldıktan sonra müşterinin ölmesi halinde ise mirasçılar sözleşme ile bağlı olacaktır. Sözleşme kapsamında taahhüt edilen geri ödeme borcunu ifa etmeye mirasçılar devam edecektir. Ayrıca, 6361 sayılı Kanun m. 3/1- k'da tahsisat ödemesinin mirasçılar adına satıcıya yapılacağı öngörülmesi de müşterinin ölümünün sözleşmeyi sona erdirmediği, müşterinin kanuni mirasçılarının sözleşme tarafi haline geleceği anlaşılmaktadır. Müşteri fiil ehliyetinin kaybı halinde de yasal temsilcisi onun adına ve hesabına ödemeleri yapacaktır.

Müşteri borcunu ödemede acze düşerse veya iflas ederse, bu durumda şirket TBK. m. 98'e dayanarak borcunu ifa etmekten imtina edebilecektir.

\section{B. Cayma Hakkı}

Kanun'un 39/A, f. 3 ve Yönetmelik'in 16, 17 hükümlerinde müşterinin cayma hakk1 düzenlenmiştir. Müşteri, sözleşmenin imzalanmasından itibaren on dört gün içinde hiçbir gerekçe göstermeksizin ve cezai şart ödemeksizin sözleşmeden cayabilir. Cayma hakkı, sözleşmenin asgari unsurları içinde yer alır ve sözleşmede cayma hakkına dair detaylı düzenleme yapılması gerekmektedir. Şirketin bilgilendirme yükümlülüğü müşterinin cayma hakkını da kapsamaktadır. Şirket, sözleşmenin imzalanmasından önce müşteriye göndereceği bilgilendirme formunda cayma hakkına ilişkin de detaylı bilgi vermek zorundadır.

Müşterinin sözleşme hükümleri çerçevesinde cayma hakkını kullanması neticesinde şirket, müşteriye organizasyon ücreti dahil, herhangi bir kesinti yapılmaksızın müşteriden alınan tutarın tamamını kararın kendisine bildirilmesine takiben on dört gün içinde iade etmekle yükümlüdür. Şirketin iade yükümlülüğünün ne zamandan itibaren başlayacağı ise cayma hakkının hüküm ve sonuç doğurmaya başlayacağı an ile ilgilidir. Yönetmelik'in 17/8 hükmüne göre cayma kararı şirkete ulaştığı andan itibaren hüküm ve sonuç doğurmaya başlayacaktır. Şirket bu andan itibaren on dört gün içinde de müşteriye cayma hakkı kapsamında iade etmesi gereken tutarı ödeme yükümlülügü altındadır. Şirket iade ile yükümlü olduğu geri ödemeleri tasarruf fon havuzunda, biriken tutarların toplandığı havuzdan yapacaktır.

Kanun veya Yönetmelik'te cayma bildiriminin geçerliliği için bir şekil şartı öngörülmemiştir. Bu kapsamda cayma hakkının kullanılmasında uyulacak şekli taraflar sözleşme kapsamında belirleyeceklerdir. Kanaatimizce cayma bildiriminin şeklinin en azından tasarruf finansman sözleşmesi kapsamında öngörülen diğer şekil şartlarında olduğu gibi yazılı şekilde veya yazılı şekil yerine geçecek (TKHK kapsamında da öngörüldüğü üzere kalıcı veri saklayıcılarında kayıt altına alınacak) uzaktan iletişim araçları ile yapılması gerekmektedir.

Cayma hakkı özellikle TKHK ve bu Kanuna dair alt düzenlemeler kapsamında birçok sözleşme için tüketiciyi korumak amacıyla tanınmış bir haktır. 6361 sayılı Kanun’da diğer finansman faaliyetlerinden farklı olarak tasarruf finansman sözleşmesi kapsamında müşteriye cayma hakkı tanınmış olması sözleşmenin niteliği itibariyle daha çok bir tüketici işlemi olarak kurulduğunun göstergesidir. 


\section{Fesih Hakkı}

Tasarruf finansman sözleşmesi ile şirket ve müşteri arasında sürekli bir sözleşme ilişkisi kurulduğu için bu ilişkiyi sona erdiren sebeplerden biri de fesih hakkıdır. Fesih hakkı sözleşmeden ya da kanundan doğan, hak sahibine tek taraflı varması gerekli bir irade beyanıyla kullanılan ve kullanıldıktan sonra da geri alınamayan bozucu yenilik doğuran bir haktır ${ }^{40}$.

6361 sayıl1 Kanun'un 39/A, f. 4 maddesinde herhangi bir gerekçe göstermeksizin müşterinin tasarruf finansman sözleşmesi ile kurulan sözleşme ilişkisini feshedebileceği düzenlenmiştir. Buna göre tasarruf finansman sözleşmesinde müşteriye tanınan fesih hakkı kanundan doğan fesih hakkıdır ve şirket karşısında sosyo-ekonomik yönden daha zayıf konumda olan müşteriyi korumak amacıyla emredici niteliktedir ${ }^{41}$. Düzenlemeye göre müşteri fesih hakkını herhangi bir sebebe dayanma ihtiyacı olmaksızın tasarruf dönemi içinde kullanabilmektedir. Müşteri, Kanun'un tanıdığı bu hakkı tasarruf dönemi bitene kadar, yani finansman dönemine geçilmemiş olması kaydıyla kullanabilir. Bunun sebebi tasarruf dönemi boyunca müşteri her ne kadar ödeme planına bağlı olarak kararlaştırılan vadelerde şirket hesabına ödeme yapıyorsa da aslında bir nevi tasarruf finansman şirketi nezdinde tasarruf birikimi yapmaktadır. Henüz finansman dönemine geçilmemiş ve finansman ödemesi yapılmamış olması sebebiyle şirkete karşı borçlanmamaktadır. Fesih hakkının sadece tasarruf dönemi ile sınırlı tutulmasının bir sebebi de fesih hakkının sonuçlarının geleceğe etkili olarak doğmasıdır. Bu durum özellikle sürekli borç ilişkilerinde edimlerin ifasına başlanmış olması halinde ifa edilen edimlerin iade edilmeyeceği esası ile ilişkilidir. Sürekli borç ilişkilerinde geçmişe etkili sonuç doğuran dönme hakkının kullanılamaması sebebiyle ifa edilen edimler geçerliliğini korumaktadır. Diğer yandan, fesih hakkının kullanılması sonucunda da feshedilen sözleşmeye bağlı bazı geri verme yükümlülükleri doğabilir ${ }^{42}$. Ancak buradaki geri verme yükümlülüğünün kapsamı yeni dönme görüşü çerçevesinde doğan tasfiye ilişkisindeki gibi değildir ${ }^{43}$. Tasarruf finansman sözleşmesinin müşterinin feshi ile sona ermesi halinde şirketin iade yükümlülüğü hususunda Kanun bazı sınırlamalar getirmiştir. Müşterinin cayma hakkında yapmış olduğu tüm birikimleri (buna organizasyon ücreti de dahildir) geri alması öngörülmüşken, fesih hakkının kullanılması halinde müşteri organizasyon ücreti dışında kalan tasarruf dönemine ait tüm tutarı alma hakkına sahiptir. Görülmektedir ki, şirketin iade yükümlülüğü kapsamı aslında müşterinin ödeme planına riayet ederek şirket nezdinde yapmış olduğu tasarruf birikimleridir. Şirket bu süre zarfında müşterinin tasarruf fon havuzunda biriken yatırımlarını yönetme borcunu ifa etmiştir. Sözleşme kapsamında müşteri şirketin yönetim borcuna karşılık organizasyon ücreti ödeme borcunu üstlenmektedir. Şirket, müşteri tarafından fesih hakkı kullanılana kadar bu borcunu ifa etmeye devam ettiği için

\footnotetext{
${ }^{40}$ Eren, 1289; Serozan, Rona. Sözleşmeden Dönme, İstanbul 1975, 121, (Serozan, Sözleşmeden Dönme).

${ }^{41}$ Eren, 1290.

${ }^{42}$ Serozan, Sözleşmeden Dönme, 119.

${ }^{43}$ Sözleşmenin geçmişe etkili olarak sona erdirilebilmesi ancak dönme hakkının kullanılması ile mümkündür. Dönme, sözleşmeye dayalı ilişkiyi geçmişe etkili olarak ortadan kaldıran bir sebeptir ${ }^{43}$. Doktrinde giderek daha fazla desteklenen "yeni dönme görüşüne" göre de sözleşme geçmişe etkili olarak ortadan kalkmaz, geleceğe etkili sonuç doğurur. Taraflar arasındaki ilişki tasfiye ilişkisine dönüşür ve bu tasfiye ilişsisinde ifa edilen edimlerin iade edilmesi (geri verme borcu) gerekecektir. Eren, 1230; Serozan, Sözleşmeden Dönme, 130 vd.
} 
organizasyon ücretinin iadesi söz konusu olmayacaktır ${ }^{44}$. Zira, fesih hakkı ifa edilen edimlerin iadesini içermemektedir ${ }^{45}$.

Şirket, fesih sebebiyle tasarruf birikimi ve varsa buna dair getirilerin iadesini Yönetmelik'in 17/8 hükmüne göre müşterinin "iadeyi talep etmesini takiben azami altı ay içinde müşterinin göstereceği kendi adına açmış olduğu banka hesabına defaten” yapacaktır ${ }^{46}$.

Kanun fesih hakkını sadece müşteriye tanımıştır. Kanun’un 39/A, f. 4 maddesinin son cümlesine göre şirketler, müşteri tarafından sözleşme yükümlülüklerinin ihlali hariç olmak üzere, tasarruf finansman sözleşmelerini tek taraflı olarak feshedemeyecektir. Bu durumda müşteri borçlarının ifasında temerrüde düşerse şirket, temerrüt hükümleri çerçevesinde TBK. m. 126 hükümlerine göre sözleşmeyi feshedebilecektir.

Yönetmelik'in 17/2 hükmüne göre fesih hakk1 da cayma hakk1 gibi şirketin bilgilendirme yükümlülüğü kapsamında olan unsurlardan biridir. Müşteri, sözleşme yapılmadan önce kendisine gönderilecek ön bilgilendirme formunda fesih hakkına dair etkin bir şekilde bilgilendirilmelidir.

\section{UYGULAMADA KARŞILAŞILAN MUHTELIF SORUNLAR}

6361 sayılı Kanun kapsamında yapılan düzenlemelerin yürürlüğe girmesi ile tasarruf finansman şirketleri ile müşterileri karşı karşıya getirecek bazı sorunlar vuku bulmuştur. Bunların başını Kanun'un geçici 7. maddesinde düzenlenmiş olan tasarruf finansman şirketleri için intibak süreci çekmektedir. Maddenin birinci fikrasına göre, "Bu maddenin yürürlüğe girdiği tarihte tasarruf finansman faaliyeti yürütenler, yürürlük tarihinden itibaren bir ay içinde Kuruma başvuruda bulunmak, başvuru sırasında durumlarını en geç altı ay içinde Kanun hükümlerine uygun hâle getireceklerine veya müşteri hak ve menfaatlerini zarara uğratmadan tasfiye olacaklarına dair bir plan sunmak ve planın uygun görülmesi hâlinde gereken işlemleri planda belirlenen süreler içerisinde yerine getirmek zorundadır". İntibak süreci Kurul'un uygun görmesi ve ek bir plan sunulması kaydıyla altı ay daha uzatılabilir. İntibak süreci içinde "Kuruma başvuruda bulunan şirketlerden, varlıklarının yükümlülüklerini karşılayamayacă̆ tespit edilenler ile durumlarını öngörülen süre içerisinde bu Kanun hükümlerine uygun hâle

\footnotetext{
${ }^{44} 6361$ sayılı Kanun'da organizasyon ücretinin tamamen iade kapsamı dışında tutulduğu görülmektedir. Müşterinin fesih hakkını sözleşmenin imzalanmasından bir ay geçtikten sonra kullanması ile yedi ay sonra kullanması arasında şirketin yönetim borcunu ifasında farklılık olacaktır. Şirketin sözleşme gereği alacağı organizasyon ücreti bedeli düşünüldügünde (düzenleme öncesi sözleşmelerde 20.000, 30.000 TL vb. gibi ücretler alınmaktaydı) müşteri bir ay sonra fesih hakkını kullandığında şirketin fahiş bir edinim elde etmesi söz konusu olacaktır. Uygulamada da sık sık müşteriler tarafından şikâyet konusu haline gelen bir durum, düzenleme öncesi sözleşmelerde fesih hakkını kullanan müşterilere organizasyon ücretinden büyük bir kısmında kesinti yapıldıktan sonra müşteriye iade edilmesiydi. Örneğin; 30.000 TL organizasyon ücreti ödeyen bir müşteriye 8.000 TL iade ediliyordu. Ancak yeni hükümlere göre organizasyon ücreti hiçbir şekilde iade kapsamında değildir. Bu hüküm fesih hakkının sonuçları ile uyuşuyor olsa da açıkladığımız sebeplerle, en azından fesih hakkının kullanıldı̆̆ organizasyon ücretinin de iade edilmesi kanaatimizce müşterinin korunması açısından yerinde olacaktı.

45 İade kapsamı dışında olan bir husus da şirketin tasarrufların yönetiminden elde ettiği getirilerdir. Sözleşme kapsamında getirilerin müşteriye ödenmesi kararlaştııılmamışsa bu getiriler tasarruf fonu içinde ihtiyat fonu olarak ayrılmaktadır. Müşteriye ödenecek getiriler de tasarruf birikimine aktarılacaktır.

${ }^{46}$ Fesih bildiriminin şekli konusunda da Kanun veya Yönetmelik’te bir hüküm yoktur. Bu kapsamda cayma hakkının kullanılmasında olduğu gibi fesih hakkında da yazılı şekilde veya yazılı şekil yerine geçecek (TKHK kapsamında da öngörüldüğü üzere kalıcı veri saklayıcılarında kayıt altına alınacak) uzaktan iletişim araçları ile yapılmasının gerektiği kanaatindeyiz.
} 
getirmeyenler veya sunduğu plan Kurul tarafindan yeterli görülmeyenler ile Kuruma başvuruda bulunmayan şirketlerin tasfiyesine karar verilebilecektir".

Şirketler Kanun'da öngörülen bu intibak sürecini tamamlamak için Kurum'a başvuruda bulunmuşlardır. Ancak Kanun'un yürürlüğe girmesinden önce yaptıkları sözleşme kapsamında tahsisata hak kazanan müşteriler, zamanı gelen tahsisat ödemelerinin gerçekleştirilmesi için şirketlere başvuruda bulunmakta iseler de şirketler intibak sürecinde oldukları için altı aydan önce tahsisat ödemesi yapamayacaklarını gerekçe göstererek tahsisat ödemesi borcunun ifasından imtina etmektedirler. Bu durumda şirketlerin muaccel olan ve ifası talep edilen borçlarını ifa etmemeleri halinde borçlu temerrüdünün şartlarının gerçekleşip gerçekleşmediğinin incelenmesi gerekmektedir.

Şirketlerin, ödemeden imtina etmelerinin dayanağ 1 intibak sürecidir. Tasarruf finansman şirketlerinin intibakını düzenleyen geçici 7. maddede açıkça sözleşme hükümlerinin askıya alındığından veya bu dönemde tahsisat ödemelerinin erteleneceğinden bahsedilmemektedir. Maddenin beşinci fikrasında, "Durumlarını bu Kanun hükümlerine uygun hâle getirerek intibak eden tasarruf finansman şirketlerinin bu maddeyi ihdas eden Kanunun yürürlük tarihi öncesinde akdettikleri tasarruf finansman faaliyeti kapsamındaki sözleşmeler bu Kanun ve ilgili mevzuat hükümlerine göre tadil olmaksızın uygulanmaya devam olunur" hükmü yer almaktadır. Bu hükümde örtülü bir ifade ile şirketlerin intibak süreçlerini tamamlamış olmaları halinde Kanun'un yürürlük tarihinden önce yapılmış olan sözleşme hükümlerinin uygulanmaya devam edeceği ifadesi ile aslında geçici bir askı hali öngörüldügü anlaşılmaktadır. Ancak askı sürecinde müşterilerin sözleşme kapsamında ödemeyi borçlandığı edimlerin akıbeti belirtilmemiştir. Bu sebeple müşteriler intibak sürecinde de tasarruf dönemine ait ödemelerini ifa etmeye devam etmektedirler.

Diğer yandan Kanun'da geçici bir askı hali öngörülmüş olsa bile bu durum Borçlar Hukuku anlamında şirketin temerrüde düştüğü gerçeğini değiştirmemektedir. Zira, borçlu temerrüdü için borçlunun kusurlu olması aranmaz, ifanın gecikmiş olması yeterlidir. Dolayısıyla şirketler tahsisat ödemesinin yapılmamasında kusurlu olmasa dahi şirket temerrüde düşer ve müşteri diğer şartların gerçekleşmesi halinde borçlu temerrüdüne dair talep haklarını şirkete karşı kullanabilecektir. Ancak şirketin kusurunun olmaması müşterinin temerrüt sebebiyle kusur şartı aranan tazminat taleplerinin kullanılmasinı engelleyecektir ${ }^{47}$.

Kanun'un yürürlüğe girmesinden önceki dönemde müşteriler tarafından s1k sık şikâyet konusu yapılan bir husus da fesih hakkının kullanılması halinde şirketlerin iade borçlarını altı ay veya daha uzun vadelerde ifa etmesidir. Kanun, fesih hakkının kullanılması halinde iade süresinin Kurul tarafından belirlenecek süre içinde müşteriye iade edileceğini kabul etmiştir. Bunun üzerine Yönetmelik'in 17/8 hükmü ile fesih hakkının kullanılması durumunda şirketin iade talep tarihinden itibaren azami altı ay içinde ödemeyi defaten, müşterinin göstereceği bir hesaba yapması gerekmektedir. Mevcut düzenleme ile iade süresi azami altı ay ile sınırlandırılmış olsa da bu süre müşterinin her halükârda mağdur olmasına sebep olacaktır. Sahip olduğu tüm birikimi şirket havuzunda toplanan ve konut, işyeri veya taşıt ihtiyacını da henüz giderememiş olan müşterinin tüm yatırımının en kısa zamanda kendisine ödenmesi gerekir. Diğer yandan, şirketler

${ }^{47}$ Eren, 1127 vd.; Buz, Vedat. Borçlunun Temerrüdünde Sözleşmeden Dönme, Ankara 1998, 100. 
bu hükmü kendi lehlerine yorumlayarak altı aydan önce iade yükümlülüğünü yerine getirmeyebileceklerdir. Sonuç itibariyle yatırım ne kadar şirket havuzunda kalırsa bu süre zarfında şirket tarafindan getiri elde edilmeye de devam edilecektir. Ayrıca azami altı aylık sürenin belirlenmesinde hangi kriterlerin esas alındığı muğlaktır. Bu sebeplerle yönetmelikte Kurul tarafından belirlenen iade süresinin müşteri mağduriyetini önlemek adına daha makul bir süreye indirilmesi, en azından bu sürenin maksimum iki veya üç ayı geçmemesi gerektiği kanaatindeyiz.

\section{SONUÇ}

Hukukumuz açısından yeni bir kavram olan tasarruf finansman sözleşmesi 6361 sayılı "Finansal Kiralama, Faktoring, Finansman ve Tasarruf Finansman Şirketleri Kanunu" ile hukukumuza girmiştir. Mevcut düzenleme öncesi de birçok firma tarafından yürütülen, İslami finansman modeli olarak kabul edilen tasarrufa dayalı faizsiz finans sistemine gösterilen ilginin fazla olması, firma sayılarındaki artış, sistemin ve firmaların güvenilirliğinin sorgulanmasına sebep olmuş zamanla artan müşteri şikayetleri ile de bu sistemin denetime tabi olması gerekliliğini ortaya koymuştur. Bu kapsamda 6361 sayılı Kanun ve buna ilişkin çıkarılan "Tasarruf Finansman Şirketlerinin Kuruluş ve Faaliyet Esasları Hakkında Yönetmelik” ile bu sisteme finansman temini için başvuran müşterilerin sözleşmenin güçlü tarafi olan şirketlerin tek taraflı, baskın ve keyfi tutumlarının önlenmesi, şirketlerin BDDK'nın denetine tabi tutularak sistem harici faaliyetlerine engel olunması ve müşteriler açısından hak mağduriyetlerinin ortadan kaldırılması amaçlanmıştır. Ancak, Kanun ve Yönetmelik kapsamında müşteri aleyhine sonuç doğuran birçok hususa dair yeterli, açıklayıcı ve müşteriyi koruyucu nitelikte emredici veya tamamlayıcı hükümler getirilmemiş, çerçeve nitelikli sözleşme hükümleri ile sözleşme kapsamında belirlenmesi tarafların mutabakatına bırakılmıştır. Böyle bir durumda her ne kadar mevzuat gereği sözleşmede bulunması gereken asgari birçok unsurunun "genel faaliyet ilkeleri dokümanı" altında BDDK'nın onayını almış olması gerektiği öngörülse de çerçeve sözleşme niteliğine haiz genel işlem koşulları içeren bir sözleşmede müşterinin ne kadar söz sahibi olabileceği şüphelidir.

Yaptığımız değerlendirmeler neticesinde, ticari amaçlı sözleşmeler dışında şirket ve müşteri arasında kurulan tasarruf finansman ilişkisi bir tüketici ilişsisidir. Mevcut düzenlemelerdeki yetersizlikle tüketici/müşteri aleyhinde olan sözleşme maddelerinin, tüketici ilişkisi sayılan hallerde "haksız şart" açısından, TKHK hükümlerinin yetersiz olduğu veya bu kapsam dışında kalan hallerde de TBK. m. 20 vd. gereğince denetlenmesi gerekecektir.

Tasarruf finansman şirketlerinin faaliyet alanlarının ve tasarruf finansman sözleşmesinin konusu Kanun gereği konut, çatılı iş yeri ve taşıt ile sınırlandırılması tasarruf finansman faaliyetinin yeknesaklığı, sistemin güvenilirliği ve denetimi açısından da yerinde olmuştur.

Müşteri lehine olan ve en azından müşterinin sözleşmenin kurulmasından önce, süreç ve sistem hakkında detaylı bilgi sahibi olması imkanını sağlayacak bir diğer hüküm sözleşme öncesi bilgilendirilme yükümlülüğüdür. Ancak, Yönetmelik'in 16/5 maddesinde şirketin, sözleşmenin kurulmasından en az bir gün önce sözleşmenin ön bilgilendirme formunu müşteriye iletilmesini zorunlu tutmuştur. Kanaatimizce müşteriye verilen bu süre yetersizdir. Zira, sistem hakkında önceden bilgisi olmayan, şirketle sözleşme görüşmelerine başlamadan da detaylı bilgi sahibi olması mümkün olmayan müşteriye kendisini uzun süre yükümlülük altına sokacak bir ilişkiye girmeden son kez detaylı düşünme ve araştırma imkânı tanınmalıdır. Şirketler benimseyecekleri 
işleyiş politikaları ile bilgilendirme formunu sözleşmenin yapılmasından bir gün önce göndererek hem bu yükümlülüğünü ifa etmiş olurlar hem de müşteriyi acele ettirerek sözleşmeden vazgeçme ihtimalini ortadan kaldırmaya çalışabilirler. Müşteri aleyhine sonuç doğuracak şirket uygulamalarının da önüne geçmek adına, müşterinin lehine olacak şekilde bilgilendirme süresinin "makul bir süre" ibaresi ile değiştirilmesi gerekmektedir.

Mevcut düzenlemeler kapsamında müşteriye cayma ve fesih hakkı tanınmış ancak bu hakkın kullanıma dair bildirimlerin nasıl yapılması gerektiğine dair Kanun'da ve Yönetmelik'te herhangi bir hüküm tesis edilmemiştir. Bu hususa dair esasların yine sözleşme kapsamında belirlenmesi öngörülmüşse de müşterinin korunması açısından en azından müşteriye ispat kolaylığı sağlayacak bildirim usullerinin Kanun veya Yönetmelikte hüküm altına alınması gerekirdir. Müşterinin cayma ve fesih bildirimlerini en azından yazılı şekilde veya yazılı şekil yerine geçecek, kalıcı veri saklayıcılarında kayıt altına alınacak uzaktan iletişim araçları ile yapılmasının lehe olacağı kanısındayız.

Müşteriler tarafından da sıkça şikâyet konusu haline gelmiş olan fesih hakkının kullanılması halinde şirketin organizasyon ücretini iade etmeyeceği hükmü, fesih hakkının sonuçlarının geleceğe etki doğuran bir müessese olması sebebiyle, kısmen yerindedir. Şirket müşteri tarafından sözleşmenin kurulmasından itibaren biriken yatırımları yönetme borcunun karşılığında organizasyon ücreti almaktadır. Ancak, müşteri tasarruf dönemi içinde sisteme dahil olduktan çok kısa bir süre sonra da fesih hakkını kullanabilir. Bu durumda şirket tarafından çok k1sa sürecek bir yönetim faaliyeti neticesinde yüksek tutarlardaki organizasyon ücretinin tamamen iade dışında tutulması hakkaniyete aykırıdır. Bu sebeple en azından müşterinin fesih hakkını kullanana kadar sistemde kaldığı süre ile orantılı olarak belirli oranlarda kesintiler yapılması suretiyle müşteriye iade edilmesi müşterinin korunması açısından lehe olacaktır.

Sıkça şikâyet konusu haline gelmiş bir husus da müşterinin fesih hakkının kullanılması halinde şirketin iade yükümlülüğünü ifa edeceği süre ile ilgilidir. Yönetmelik'in 17/8 hükmünde öngörülen azami altı aylık iade süresi tüm birikimi şirket havuzunda toplanan müşterinin her halükârda mağdur olmasına sebep olacaktır. Mevcut düzenleme ile iade süresi azami altı ay ile sınırlandırılmış olsa da şirketler bu hükmü kendi lehlerine yorumlayarak altı aydan önce iade yükümlülüğünü yerine getirmeyebileceklerdir. Kurul tarafından belirlenen iade süresinin müşteri mağduriyetini önlemek adına daha makul bir süreye indirilmesi, en azından bu sürenin maksimum iki veya üç ayı geçmemesi gerektiği kanaatindeyiz.

Son olarak, şirketlere Kanun gereği tanınan intibak sürecinde tahsisat borçlarını ödemeden imtina etmeleri, şirketlerin borçlu temerrüdüne düşmesine sebep olacaktır. Şirket açısından intibak sürecinde olmak hâkli neden teşkil etse, hatta mevcut düzenleme geçici bir askı olarak yorumlansa dahi borçlu temerrüdünün gerçekleşmesi için borçlunun kusuru şart olmadığı için temerrüdün diğer şartlarının gerçekleşmesi halinde şirket temerrüde düşecektir. Şirketin kusursuz oluşu müşterinin temerrüde dayalı kusur şartı aranan tazminat taleplerini engellemekten öteye gitmeyecektir. 


\section{KAYNAKÇA}

Afşar, Aslı. Finansal Gelişme ile Ekonomik Büyüme Arasındaki İlişki, Muhasebe ve Finansman Dergisi, S. 36, 2007, 189 vd., https://dergipark.org.tr/tr/pub/mufad/issue/35607/395635, (E.T. 21.03.2021).

Akbulak, Yavuz. Türk Finans Hukukunda Yeni Bir Kurum: "Tasarruf Finansman”, Legal Blog, 2021, 2, https://legal.com.tr/blog/genel/turk-finans-hukukunda-yeni-bir-kurum-tasarruf-finansman, (E.T. 09.04.2021).

Akıncı, Şahin. Borçlar Hukuku Bilgisi, 11.B., Konya 2020.

Altık Ormancı, Pınar. Sürekli Borç İlişkilerinin Haklı Sebeple Feshi, İstanbul 2011.

Antalya, Gökhan. Borçlar Hukuku Genel Hükümler Cilt. V/1, 1, 2.B., Ankara 2019.

Arat, Ayşe. Konut Satışında Üç Köşeli İlişkilerden Doğan Sorumluluk, İstanbul 2018.

Bellican, Cüneyt. 6502 Sayılı Tüketicinin Korunması Hakkında Kanun Kapsamında Bilgilendirme Yükümlülüğünün Değerlendirilmesi, İstanbul Kültür Üniversitesi Hukuk Fakültesi Dergisi, C. 16, S. 2- 1, Temmuz- Ağustos 2017, 305, https://www.jurix.com.tr/article/9664, (E.T. 17.04.2021).

Beybur, M./Çetinkaya, M.. Tasarrufa Dayalı Faizsiz Finans Sistemine Jak Bankacılık ve Karz-I Hasen Sistemi Önerisi, The Journal of Social Science, C: 5, S: 9, 2021, (DOI: 10.30520/tjsosci.880196, E.T. 25.03.2021).

Birsin, Mehmet/ Ötegeçeli, Hatice. Tasarrufa Dayalı Faizsiz Finansman Sistemi ve Fıkhî Meşruiyeti Üzerinde Yapılan Değerlendirmeler, Mesned İlahiyat Araştırmaları Dergisi, C. 10, S. 1, 2019, 87 vd., https://dergipark.org.tr/tr/pub/mesned/issue/46608/584675, (E.T. 11.04.2021).

Buz, Vedat. Borçlunun Temerrüdünde Sözleşmeden Dönme, Ankara 1998.

Çekin, Ömer. Tasarrufa Dayalı Finansman Sistemi ve İslami Finans İlkeleri Çerçevesinde Değerlendirilmesi, İstanbul Üniversitesi Sosyal Bilimler Enstitüsü, İslam İktisadı ve Finansı Anabilim Dalı, (Yayınlanmamış Yüksek Lisans Tezi), 2018.

Ercoşkun Şenol, Kübra. "Sözleşmenin İçeriğini Belirleme Özgürlüğü ve Bunun Genel Sınırı: TBK M. 27", $\ddot{I} \ddot{U} H F M$, C. 74, S. 2, 2016, 724, https://dergipark.org.tr/tr/download/article-file/292465, (E.T. 16.04.2021).

Eren, Fikret. Borçlar Hukuku Genel Hükümler, 4. B., Ankara 2017.

Gonzenbach, Rainer. Culpa in contrahendo im schweizerischen Vertragsrecht, Bern 1987.

Karahan, Hediyatullah/ Ersoy, Hicabi. Faizsiz Finansin Temel Prensipleri ile Türkiye'de Reel Kesimde Kullanılmas1, Maliye ve Finans Yazllarl, C. 0, S. 105, 2016, 95 vd., https://dergipark.org.tr/tr/download/article-file/302022, (E.T. 17.04.2021).

Kılıç, Selim. Konut Finansman Modeli Olarak Yapı Tasarruf Sandıkları; Almanya ve Türkiye'deki Uygulamaları, Yönetim ve Ekonomi, Celal Bayar Üniversitesi İktisadi ve İdari Bilimler Fakültesi Dergisi, C. 14, S. 1, https://dergipark.org.tr/tr/pub/yonveek/issue/13686/165630, (E.T. 11.04.2021).

Kuntalp, Erden. Ard Arda Teslimli Satım Akdi, Ankara 1968.

Okur, M./ Çatıkkaş, Ö./ Ersoy, M.. Bir Gölge Bankacılık Uygulaması Olarak Gayrimenkul Finansmanında Alternatif Bir Faizsiz Finansman Modeli: İpoteğe Dayalı Paylaşımlı Faizsiz Finansman Modeli, Işsletme Araştırmalart Dergisi, $\quad 10 / 4, \quad 2018$, https://www.isarder.org/2018/vol.10_issue.4_article19_full_text.pdf, (E.T. 25.03.2021).

2014.

Oğuzman, K./ Öz, T.. Borçlar Hukuku Genel Hükümler, C.1, Gözden Geçirilmiş 12. B., İstanbul 
Seliçi, Özer. Sözleşmeden Doğan Sürekli Borç İlişkilerinin Sona Ermesi, İstanbul 1977.

Serozan, Rona. Sözleşmeden Dönme, İstanbul 1975, (Kısaltma: Serozan, Sözleşmeden Dönme).

Serozan, Rona. "Culpa In Contrahendo”, “Akdin Müspet İhlali” ve "Üçüncü Kişiyi Koruyucu Etkili Sözleşme” Kurumlarının Ortak Temeli: Edim Yükümlülüklerinden Bağımsız Borç Illişkisi, İstanbul Üniversitesi Mukayeseli Hukuk Araştırmaları Dergisi, C. 2, S. 3, 1968, https://dergipark.org.tr/tr/pub/iumhad/issue/1282/15108, (E.T. 15.04.2021).

Tekinay, Selahattin Sulhi/ Akman, Sermet/ Burcuoğlu, Haluk/ Altop, Atilla. Borçlar Hukuku Genel Hükümler, 7. B., İstanbul, 1993.

Tuna, Abdulkadir. Finansal Ekonomi, İstanbul Üniversitesi Açık ve Uzaktan Eğitim Fakültesi, https://cdn-acikogretim.istanbul.edu.tr/auzefcontent/20_21_Guz/finansal_ekonomi/2, (E.T. 21.03.2021).

Ulusan, İlhan. Culpa in Contrahendo Üstüne, Prof. Dr. Ümit Doğanay'ın Anısina Armağan 1, İstanbul 1982.

Yavuz, Cevdet. Borçlar Hukuku Dersleri (Özel Hükümler), 13. B., İstanbul 2014.

Von Thur, Andreas. (Çev. Cevat Edege), Borçlar Hukuku, C. 1, İstanbul 1952. 